\title{
Where does the modality of Ancient Greek modal verbs come from?
}

\section{The relation between modality and oblique case marking*}

\author{
Serena Danesi \\ University of Bergen \\ srn.dns@gmail.com \\ Cynthia A.Johnson \\ Ghent University \\ cajohnso6@gmail.com \\ Jóhanna Barðdal \\ Ghent University \\ Johanna.Barddal@ugent.be
}

\begin{abstract}
Modality can be expressed through a variety of different linguistic means within and across languages, of which one manifestation is through noncanonical case marking of the subject. In Ancient Greek several predicates show a systematic alternation between constructions with nominative and oblique subjects, which coincides with a difference in meaning, yielding a modal meaning in the latter case. We show how this modal meaning cannot be derived from the meaning of the individual parts of the construction, neither from the lexical material nor from the relevant grammatical elements. Instead, the data call for a constructional analysis of a modal subconstruction of the oblique subject construction, for which the modality must be attributed to the con-
\end{abstract}

* For comments and discussions, we thank two anonymous reviewers of JGL, the editors of JGL, as well as the audiences in Bergen (2014), Ghent (2014), Kviknes (2015) and Naples (2015), where earlier versions of this work were presented. This research was supported with two generous research grants to Jóhanna Barðdal (PI): from i) the Norwegian Research Council (NonCanCase, grant nr. 205007) and ii) the European Research Council (EvAlisA, grant nr. $313461)$.

(C) SERENA DANESI, CYNTHIA A. JOHNSON AND JÓHANNA BARĐDAL, 
struction itself. We argue that this can be viewed through the lens of subjectification in the sense of Traugott (2003), here demonstrating that the semantic relation holding between the subject referent and the oblique case marking selected by the verb has been extended to the empathic relation holding between the speaker and his/her attitude towards the proposition uttered (Barðdal 2004). This, we believe, is how the concept of modality came to be associated with oblique case marking of subjects.

\section{Keywords}

Ancient Greek - modality - oblique subjects - noncanonical case marking - Construction Grammar

\section{Introduction}

Studies on the grammatical expression of modality in Ancient Greek (Goodwin 1966, Horrocks 1995, Seiler 1971, Willmott 2007, inter alia) focus on diverse grammatical devices, such as tense, mood, modal particles like án, $k e$, and $k a$, and verbal adjectives, all of which are used in Ancient Greek to express deontic and epistemic meaning.

In addition to such grammatical strategies, modality can also be expressed with modal predicates, which are the topic of the present study. Earlier research exists on the semantics of some of these modal verbs: Goodell (1914) investigates khré 'be necessary' and dề 'need' and attributes the modal value of the English must to dề and the modal meaning of the English should to khré. Redard (1953), in his monograph on khrế 'be necessary' and khrêsthai 'make use', considers de $\hat{\imath}$ an expression of objective modality - a necessity imposed by an authority or by a particular situation — and khrế to be an expression of internal need. Benardete (1965) provides a philosophical analysis of these verbs: he connects dề to the notion of nomós intended as an objective and external 'law' or 'need', while he associates khré with self-interest. Finally, Ruiz Yamuza (2008) includes in her analysis one more modal verb, opheílo; she examines in detail the modal meanings associated with all of the three verbs (varying from necessity, deontic necessity, and epistemic necessity, together with other various modal nuances) and the diachronic semantic shift undergone by these verbs.

Ruiz Yamuza (2008: 180) argues that a metaphorical extension of these constructions, supposedly grounded in the metaphorical construct in which ideas - and further, obligations - are objects, is particularly relevant to the shift in the meaning of these original nominative subject verbs. It follows from 
Ruiz Yamuza's analysis that the relevant modal verbs have developed from nominative subject verbs with no (or a different) modal meaning to verbs expressing modality when occurring in the oblique subject construction.

Apart from these earlier studies, which are confined to a restricted number of verbs, the realm of Ancient Greek modal predicates is relatively unexplored. In fact, since these predicates are often used impersonally and occur in periphrastic structures with infinitives, they are typically grouped together with impersonal verbs and analyzed as such. Moreover, the majority of the earliest studies discuss primarily differences in meaning, without a full discussion of concomitant syntactic properties.

The aim of this article is to provide an overview of modal predicates in Ancient Greek, and to suggest an update of the standard analyses. We propose that the combination of a modal verb with a dative or an accusative designating the locus of modality instantiates an oblique subject construction that is semantically and pragmatically motivated; specifically, the construction is a result of a process of subjectification, whereby some speaker-oriented pragmatic implicatures are grammaticalized. In contrast to previous work on the semantics of modal verbs, our study contributes to the understanding of the whole construction alongside similar, nonmodal constructions that occur with the same noncanonical argument structure.

The present proposal is advanced within the theoretical framework of Construction Grammar (Lakoff 1987; Fillmore et al. 1988; Goldberg 1995, 2006; Croft 2001; Michaelis \& Ruppenhofer 2001), which allows for the possibility of assuming a constructional meaning associated directly with the oblique subject construction. As such, it also allows for a novel analysis, according to which the modal structure is regarded as a subconstruction of an abstract and more schematic oblique subject construction.

In Section 2, we present the basics of Construction Grammar and introduce evidence for a subject analysis of the oblique subject-like argument, before giving a full account of how the data described in this study were gathered. Then we discuss in some detail the notion of modality and analyze its conceptual space represented through a semantic map (Section 3). After that, we examine the Ancient Greek predicates of necessity and possibility, taking into account both the syntactic frame in which they occur and the relation between their nonmodal (or literal) and their modal meaning (Section 4). In Section 5, we explain the combination of a dative or an accusative argument with a modal verb as an instantiation of an oblique subject construction, and we account for the modal meaning in terms of constructional meaning rather than as a result of a diachronic semantic shift. Finally, our findings are summarized in Section 6 . 
In this section, we start by laying out the basics of the framework adopted in the present article, Construction Grammar (Section 2.1), before we set the stage for our subject analysis of the oblique subject-like argument occurring in the oblique subject construction in Ancient Greek (Section 2.2). Section 2.3 accounts for the data and how it has been collected.

\subsection{Construction grammar}

The analysis suggested below is carried out within the framework of Construction Grammar (as developed in Lakoff 1987; Fillmore et al. 1988; Goldberg 1995, 2006; Croft 2001; Michaelis \& Ruppenhofer 2001, inter alia). This approach is particularly appropriate for our analysis for several reasons. To begin with, Construction Grammar assumes no strict separation between the lexicon and the syntax; the grammar of a language is not structured in distinct 'modules'; rather, the grammar is monostratal and therefore entails only one level of analysis, the surface level. The surface level is not derived from a deeper level by means of specific rules of transformation. Moreover, the notion of construction is central for the framework of Construction Grammar, since constructions-as formmeaning pairings which may be larger than words, and even as large as entire clauses - are taken to be the basic units of language. With this approach, the grammar is viewed in terms of a constructiCon, which is similar to a lexicon except that it contains constructions larger than entities at the lexical level. The constructiCon consists of an inventory of constructions which are interrelated in different ways (cf. Levshina 2012; Traugott \& Trousdale 2013: Ch. 2; Trousdale 2013; Hilpert 2014: Ch. 3; Barðdal \& Gildea 2015: 22-25; Torrent 2015).

Second, to define the combination of a modal predicate with an argument designating the locus of modality, we use the term oblique subject construction. This term refers to argument structure constructions instantiated by predicates, where the subject-like argument is not in the nominative case, but in a different case, e.g., in the dative, accusative, or genitive case (cf. Barðdal \& Eythórsson 2003, 2012; Eythórsson \& Barðdal 2005). We further assume that constructions exist at different levels of schematicity, including concrete predicate-specific constructions, as well as more schematic constructions (cf. Croft 2003; Barðdal 2001a, 2008; Barðdal \& Eythórsson 2012, inter alia).

Any analysis of modal predicates in Ancient Greek must take into account the interaction between the noncanonical case frame and the predicate, which together count as the flag morphemes of the construction. Since case markers constitute a part of constructions, namely of argument structure constructions, cases must be studied in relation to their argument structure construc- 
tions (Barðdal 2001b, 2009; Fried 2005). In other words, the fact that these predicates exhibit a modal meaning only in combination with noncanonically case-marked subjects calls for a constructional account of modal predicates in Ancient Greek, as the locus of modality is not the verbal predicate itself, but rather the co-occurrence of the two.

Third, following Langacker (1987), Talmy (1988), Croft (1998, 2001), and Barðdal (2001a), we adopt a causal chain approach to argument realization. This causal chain approach represents events as a causal chain conceptualized by the speaker, linking participants in the event in terms of transmission of force from one participant to the other. The transmission of force and the consequent force-dynamic relations between participants in the event determine the argument realization and, hence, the assignment of the subject and the object roles to participants of the event.

Given these assumptions, we analyze the combination of a modal verb and a dative or an accusative subject-like argument denoting the locus of modality as instantiations of an oblique subject construction, in the sense outlined above, whose shape is determined by the causal structure of the event and the force-dynamic relation holding between the participants (cf. also Eythórsson \& Barðdal 2005; Barðdal et al. 2014).

\section{$2.2 \quad$ Subject status}

The insight that there may be syntactic subjects in morphological cases other than the nominative first started to circulate in the late 1970's with the work of Andrews (1976) on Icelandic and Masica (1976) and Klaiman (1980) on the South Asian languages. It is by now generally accepted in the field of modern linguistics that there is no one-to-one relation between nominative case on arguments and subject status (cf. Barðdal 200oa) and that behavioral properties of subjects are not only found with nominative subjects, but also with arguments in other morphological cases like accusative, dative, and genitive arguments. The most widely-used behavioral properties used to develop this argumentation are the following:

- Neutral word order in main-clause declaratives

- Subject-verb inversion

- Neutral word order in subordinate clauses

- Reflexivization

- Conjunction Reduction

- Raising-to-subject

- Raising-to-object

- Control infinitives 
Subject tests like those above have been found to apply to language after language, including languages that are not genealogically related, although certain tests are difficult to apply in some languages due to the nature of the grammar. Neutral word order, for instance, becomes difficult to apply in pro-drop languages, though not impossible.

Several of the tests listed above have been successfully used on the IndoEuropean languages, both modern, medieval, and ancient. Regarding Germanic languages, it has been shown beyond doubt that the oblique in the oblique subject construction in Old Norse-Icelandic (Rögnvaldsson 1991, 1995, 1996; Barðdal 200ob; Barðdal \& Eythórsson 2003; Eythórsson \& Barðdal 2005; Barðdal \& Eythórsson 2012; Jónsson 2018), Old Swedish (Barðdal 20oob), Old and Middle English (Allen 1995; Eythórsson \& Barðdal 2005; Barðdal \& Eythórsson 2012), and Old Saxon, Old High German, and Gothic (Barðdal \& Eythórsson 2012) behaves syntactically as a subject with regard to the tests listed above. Control infinitives, which have been regarded as the most conclusive subject test by many, have been documented in Old Norse-Icelandic, Old Swedish, Middle English, and Gothic involving the oblique in the oblique subject construction. Raising-to-subject and raising-to-object are found in all the early Germanic languages, showing that the oblique in the oblique subject construction passes these tests as well. This is in addition to expected behavior regarding reflexivization and neutral word order.

For other early Indo-European languages, it has also been argued that the oblique in the oblique subject construction in Latin behaves syntactically as a subject (Fedriani 2009, 2014; Fabrizio in press) with regard to a host of subject tests. Early work on Sanskrit possessive constructions shows that the dative/genitive behaves syntactically as a subject in that language (Hock 199o). Moreover, a scrutiny of word order in two early Indo-European languages that have a fixed word order, Hittite (sov) and Old Irish (vso), also reveals a clear subject behavior; possessors in the dative possessive construction in Hittite show the same word order properties as nominative subjects (Johnson et al., in prep) and obliques in the oblique subject construction in Old Irish behave in the same manner as ordinary nominative subjects do (Le Mair et al. 2017).

Work on subject properties in Ancient Greek is ongoing (Barðdal et al. 2017; Benedetti \& Gianollo 2017), so it suffices here to illustrate the Greek situation with two examples of obliques in the oblique subject construction behaving syntactically as subjects in control infinitives. Typically, subjects in control infinitives are left unexpressed on the basis of identity with the subject of the matrix clause, the object of the matrix clause, a prepositional object of the matrix clause, or even on the basis of a referent retrievable from the context. In the following examples, the verb deî 'be in need of' occurs in the infinitive with 
its subject-like dative being left unexpressed, in both cases on identity with the subject of the matrix clause, the pro-dropped 'he' in (1a) and 'we' in (1b).
a. kai eî oiētaí
te
deîn
gráphein

and if think.3SG.SBJV and PRO.DAT be.needful.INF write.INF 'And in case he thinks he should write ...' (Plat. Theaet. 207e)

b. dià lógōn pou èphamen _ deîn through words.GEN doubtless say.1PL.IPFV PRO.DAT be.needful.INF krinesthai

decide.INF.MP

'We said that we must doubtless take judgments by means of words' (Pl. Rep. 9. 582d)

When deî occurs with a nominative subject, it always means 'lack'. However, when deî has the meaning 'be in need of', it occurs systematically with a dative, meaning that only a dative can have been left unexpressed in these examples. Hence, these examples show that the dative of deî indeed behaves syntactically as a subject in Ancient Greek. For further examples and an illustration of the remaining subject tests in Ancient Greek, see Barðdal et al. (2017).

Before we leave the issue of subject status, a note on agreement is in order. In the Indo-European languages, agreement is confined to the nominative argument in almost all cases rather than the syntactic subject (cf. Barnes 1986; Sigurðsson 1990-1991, 2006; Thráinsson et al. 2012), thus making agreement a poor test for subjecthood. Hence, with regard to the status of the verbs in the Ancient Greek modal constructions, only third person singular forms are observed in such contexts. While the connection between impersonal verb forms and changes in argument structure are frequently observed in Indo-European (cf. Cennamo 2011, Kulikov 2011, inter alia), it is also the case that third person singular is the default form of the verb in all impersonal constructions (cf. Corbett 1991: 204), not just for expressing modality; that is, whether the subject is a non-nominative argument (as in the examples given in this article), or if it is a clause, an infinitive, an expletive, etc., the verb is always third person singular.

\subsection{The collection of the data}

The data presented in Section 4 below have been collected as a part of a more general data collection conducted within the NF R-funded NonCanCase and the ERC-funded EVALISA research projects, carried out at the University of Bergen (2011-2015) and Ghent University (2013-2018), respectively. Data have been systematically collected from all 11 branches of the Indo-European language fam- 
ily, from the earliest texts and, in some cases, from later stages, either medieval or modern. The predicates cover a wide conceptual domain, of which modality is only one subdomain (cf. Barðdal et al. 2012, 2016). This data collection has resulted in an interactive mysql database containing verbs and compositional predicates selecting for oblique subjects (the NonCanCase database), which will be made available to the research community at large upon its completion.

The predicates discussed below expressing modalities in Ancient Greek were collected first via a thorough examination of three standard dictionaries: Liddell \& Scott's A Greek-English Lexicon and An Intermediate Greek-English Lexicon, and Autenrieth's A Homeric Dictionary. As a follow-up, the predicates were searched for via the Perseus database in all agreement forms, in order to document their argument structures (hence, we use the abbreviations in Perseus when denoting the sources of our examples). Our examples below with modal readings were collected in the aforementioned database. The discussion below of the different argument structures is therefore exhaustive in that it accounts for all of the Classical/Homeric Greek materials available on Perseus. All examples potentially involving pro-drop have been excluded, on the basis of an examination of the wider syntactic context. A fuller list of examples can be found in the Appendix. These are not all of the examples in the Ancient Greek corpus but rather at least one example for each author for which the modal usage can be found. Unless otherwise specified, the translations are our own.

Modality

The concept of modality is generally used to refer to the way a speaker modifies linguistic expressions of possibility, attitude, necessity, and belief. The literature abounds with definitions and descriptions of this notion (see Narrog 2005: $678 \mathrm{ff} ., 2012$ for an overview). The notional domain of modality is in fact so large and complex that it is difficult to provide an exhaustive characterization of the concept.

Here we adopt the classification of modality proposed by van der Auwera \& Plungian (1998), who define modality in terms of necessity and possibility and argue for four semantic defining dimensions along which modality can be analyzed; these are participant-internal modality, participant-external modality, deontic modality, and epistemic modality, as laid out in Table 1 (van der Auwera \& Plungian 1998).

Starting with van der Auwera \& Plungian's defining dimensions, participantinternal modality concerns possibility or necessity depending on the partici- 
Possibility

\begin{tabular}{l|l|l|l}
\hline \multicolumn{2}{c|}{ Nonepistemic possibility } & \multirow{2}{*}{$\begin{array}{l}\text { Epistemic possibility } \\
\text { (Uncertainty) }\end{array}$} \\
\hline $\begin{array}{l}\text { Participant-internal } \\
\text { possibility } \\
\begin{array}{l}\text { (Dynamic possibility, } \\
\text { Ability, Capacity) }\end{array}\end{array}$ & $\begin{array}{l}\mid c \\
\text { (Nondeontic } \\
\text { possibility) }\end{array}$ & $\begin{array}{l}\text { Deontic possibility } \\
\text { (Permission) }\end{array}$ & \\
\cline { 2 - 3 } $\begin{array}{l}\text { Participant-internal } \\
\text { necessity } \\
\text { (Need) }\end{array}$ & $\begin{array}{l}\text { (Nondeontic } \\
\text { necessity) }\end{array}$ & $\begin{array}{l}\text { Deontic necessity } \\
\text { (Obligation) }\end{array}$ & $\begin{array}{l}\text { Epistemic necessity } \\
\text { (Probability) }\end{array}$ \\
\cline { 2 - 3 } & \multicolumn{2}{|c|}{ Participant-external necessity } & \\
\hline
\end{tabular}

Necessity

FROM VAN DER AUWERA \& PLUNGIAN 1998: 82

pant in the event; basically, it refers to abilities, as exemplified in (2a), and needs, as exemplified in (2b) (examples from van der Auwera \& Plungian 1998: 8o).

(2) a. Boris can get by with sleeping five hours a night.

b. Boris needs to sleep ten hours every night for him to function properly.

The second, participant-external modality, refers to possibilities (3a) or necessities $(3 \mathrm{~b})$, which do not depend directly on the participant of the event (examples from der Auwera \& Plungian 1994: 80).

(3) a. To get to the Station, you can take bus 66.

b. To get to the Station, you have to take bus 66 .

The third, deontic modality, refers to the external circumstances which permit or oblige the participant to carry out the event, as exemplified respectively by (4a) and (4b). 
(4) a. John may leave now.

b. John must leave now.

And finally, epistemic modality concerns the evaluation of the speaker of the event, judged probable, as in example (5a), or certain, as in example (5b):

(5) a. John may have arrived.

b. John must have arrived.

Starting from the paths proposed by Bybee et al. (1994), van der Auwera \& Plungian (1998) outline a semantic map of modality and suggest possible ways for languages to express modality. That is, they provide a representation of their conceptual domain of modality, which they intend to be universal.

Moreover, in their conceptual space of modality, van der Auwera \& Plungian make predictions about possible routes of grammaticalization from a nonmodal meaning to a modal meaning. The paths leading to grammaticalization are represented as in Figure 1, which shows that across the languages of the world, modal meanings related to both possibility and necessity are often diachronically derived from verbs of different semantic areas (motion, happenstance, cognition, possession, ontological states, etc.). The grammaticalization process proceeds from the nonmodal meaning to participant-internal modality first, then to participant external modality, and finally to epistemic modality.

In the following section, Ancient Greek expressions of modality by means of modal verbs are analyzed on the basis of the criteria proposed above. This entails an investigation of both simple verbs and compositional predicates, consisting of the verb 'be' most typically together with an adjective or a noun. Furthermore, we investigate whether the modal meaning derives from the nonmodal ones, and as such, we explore the paths leading to modalization.

\section{$4 \quad$ Modal predicates in Ancient Greek}

Ancient Greek modal predicates are generally used impersonally, are constructed with an infinitive, and combine with an argument designating the locus of modality, namely, the subject of the modal event, which is not expressed with the usual subject case (nominative). Modal predicates show variation with regard to the expression of their subject: it can occur in the accusative or the dative (see e.g. Gianollo \& Lavidas 2013, 2014 on a possible connection between case and focus). This variation can take place even with the same verb 


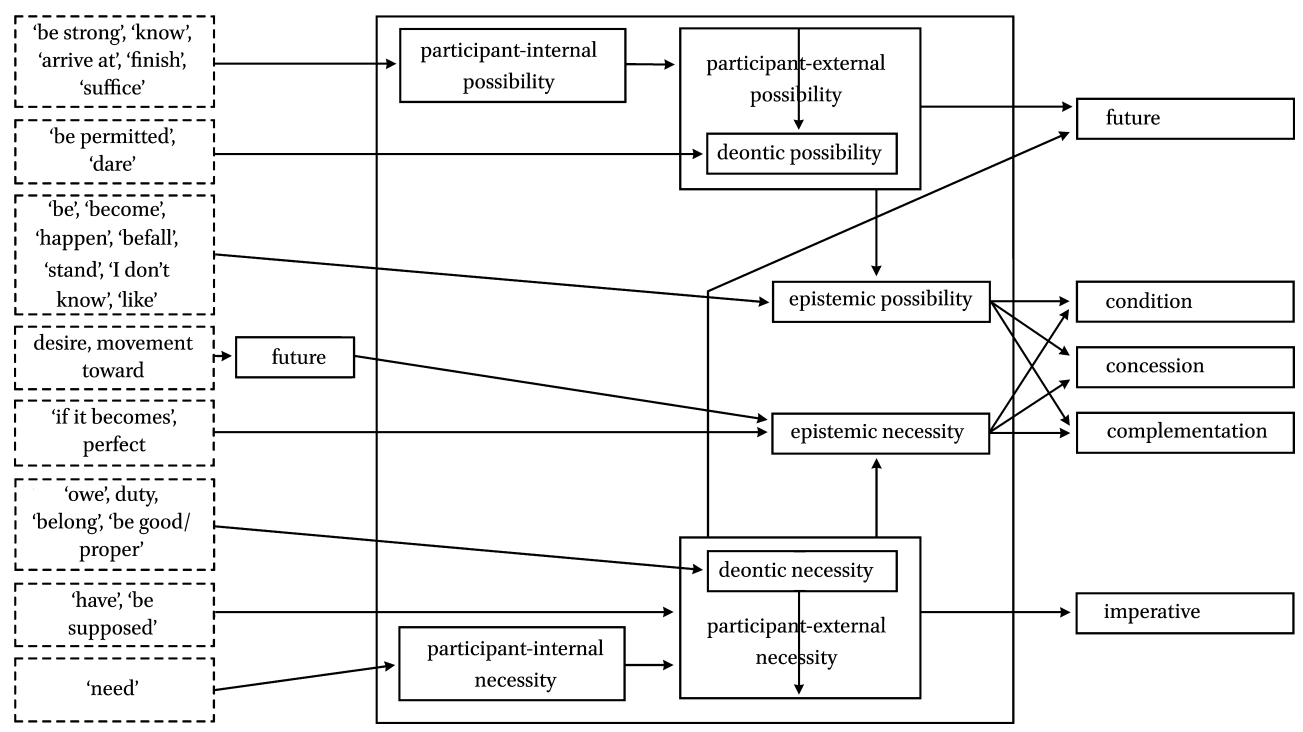

FIGURE 1 Conceptual domain of modality

FROM VAN DER AUWERA \& PLUNGIAN 1998: 98

without any noticeable semantic difference, as shown in (6) where deî takes an accusative subject in (6a) but a dative subject in (6b):

a. $t \grave{\imath} d \grave{e} d e \hat{\imath}$ polemizémenai ... Argeíous why indeed be.needful.3sg fight.INF Argives.ACC 'Why do the Argives find it necessary to fight?' (Hom. Il. 9.337)

b. theô̂si prosbaleîn khthoni állēn... deếsei gods.DAT put.to.AOR.INF hearth.DAT other.ACC be.needful.3sG.FUT gaîan world.ACC 'The gods will find it necessary to dash another world to the earth' (Eur. Hipp. 941)

However, most verbs documented in the oblique subject construction with a modal meaning also occur in personal constructions with nominative subjects. In the next sections, we present an overview of these predicates on the basis of the nature of their modal meaning (necessity or possibility) and offer examples of their occurrences in the oblique subject construction, as well as in the nominative subject construction, when such examples have been documented. Our aim is to show that the difference in meaning corresponds with the difference in form between the two constructions. 
4.1 Necessity

The expression of necessity is not exclusive to modal predicates; verbal adjectives in -téos designate modal necessity as well. Even though such verbal adjectives are not within the scope of this article (for a detailed investigation, see La Fauci \& Tronci 2013, Luraghi 2016, Danesi et al. 2017), it may be illuminating to describe them briefly, since they share an important characteristic with modal predicates, namely, the fact that they take an oblique subject. Verbal adjectives qualify a participant who has to undergo the event conveyed by the verb from which they derive. This referent, forming a patient-relation with the verbal adjective, is in the nominative, while the entity carrying out the event is expressed with the dative:
(7) ōphelètéa
soi
he pólis
estí
succor.GER.NOM you.2SG.DAT the.NOM city.NOM be.3SG.PRES
'You must succor the city' (Xen. Mem. 3, 6, 3)

Verbal adjectives can also occur in "impersonal" constructions without a nominative, as exemplified in (8). Here the verbal adjective is nominative neuter singular-téon (rarely plural -téa):

(8) têi emêi psukhêi itéon

the.DAT my.DAT soul.DAT go.GER.NOM

'at once also my soul must leave' (Plat. Phaedo 8od)

This example in (8) above is active in sense (Smyth 1963: 480, Goodwin 1966: 152), and yet the obliged participant is expressed with the dative.

Modal predicates are similar to verbal adjectives in that both express a modal meaning and occur in an oblique subject construction. Modal predicates conveying modal necessity constitute a relatively large class in Ancient Greek. These include, e.g., dề 'it is morally necessary', khré (esti) 'it is necessary', anánkè (esti) 'it is necessary', harmózei 'it is fitting', epéoika 'it is fitting, proper', epanaménei 'is expected', ménei 'is expected', opheílei 'it behooves', prépei 'it is fitting'.

In the following subsections, each of these predicates is analyzed, with special attention to their semantics and their argument structure realization, starting with dêे below. 
4.1.1 dêे

The verb dêt can occur as both a personal and an impersonal verb. The personal variant, déo, with a nominative subject, means 'lack, stand in need of':
(9) polloû déō
eg⿳亠丷厂 hupèr emautôे
much.GEN be.in.need.of.1SG.PRES 1SG.NOM upon myself.GEN
apologeîsthai
defend.INF.MP
'I am far from defending myself' (Plat. Apol. 3od)

In Greek prose, especially in Plato, Xenophon, and Lysias, the expression pollo $\hat{u}$ déo (9) is frequent and means 'I need much'. As example (9) shows, the person needing is expressed with the nominative and the thing wanted is in the genitive.

The middle variant of this verb, déomai 'be in want, require', is also documented in the early texts. It is construed like déo:
(10) éti déomai
saphésteron matheîn
still want.1SG.PRES.MP more.clearly understand.AOR.INF
'I still want to understand more clearly' (Plat. Rep. 392d)

Moreover, when dế occurs in the oblique subject construction, the meaning 'lack' can be better interpreted as 'need', although these are two closely related meanings (lack implies need, and need usually implies lack). The oblique subject construction conveys a modal meaning, specifically participant-internal need, since it designates a necessity on the behalf of the subject referent. This use is amply documented in the classical period and in this construction, the thing needed is expressed in the genitive, while the person in need can either be expressed in the dative, as exemplified in (11a), or in the accusative, as in (11b).

(11) a. soí te gàr paídōn tí dế; you.2SG.DAT and indeed children.GEN why be.needful.3SG.PRES 'Why do you need any more children?' (Eur. Med. 565)

b. autòn gár se dề oneself.ACC indeed you.2SG.ACC be.needful.3SG.PRES promēthéōs forethought.GEN 'Indeed you yourself need forethought' (Aesch. $Р в$ 86) 
The impersonal dei 'need' often occurs with an infinitive, with the subject being expressed either in the dative, as exemplified in (12a), or in the accusative, as in (12b).

(12) a. theoîsi prosbaleîn khthonil állēn deếsei gods.DAT put.to.AOR.INF hearth.ACC other.ACC be.needful.3SG.FUT gaîan world.ACC

'The gods will have to add another earth to our world' (Eur. Hipp. 941)

b. $d e \hat{\imath}$

emè

en koítēi sêi katupnôsai

be.needful.3SG.PRES I.ISG.ACC in bed your fall.asleep.AOR.INF

'I must fall asleep in your bed' (Hdt. 7.16c)

Note that deî 'need' occurring with oblique subject and an infinitive usually designates participant-external necessity. As exemplified in (12a-b), deontic necessity (obligation) is expressed. In (12a), the fact that the gods add another earth to our world is something which has to be done according to the judgment of someone else, namely Theseus, who complains that if human cruelty continues to grow, the gods will have to add another earth in order to hold all criminal and vile people. In (12b), which is part of a dialogue, the fact that the speaker has to sleep in the bed of the addressee/interlocutor is something that has been decided by the interlocutor himself, again illustrating participantexternal necessity.

In addition to expressing deontic modality, dêे 'need' can also denote epistemic modality. This takes place when a past form of deî is used with the infinitive; the expression designates an unreal condition and functions like a past indicative with án (examples from Smyth \& Messing 1956: §1770-1779, §17841789):

(13) a. édei tà enékhura tóte labeîn

need.3SG.AOR the.ACC pledges.ACc then take.AOR.INF

'I ought to have taken the pledges then' (Xen. Anab. 7.6.23)

b. égnō án tis

know.3SG.AOR PTC one.NOM

'One should/might/would/could have known' (Xen. Cyrop. 7.1.38)

It is entirely possible that some modality types are related to particular tenses or moods in Ancient Greek (cf. Ruiz Yamuza 20o8: 26-31). This, however, lies outside the scope of the present article. 
To sum up, in the nominative subject construction, déo maintains its nonmodal meaning 'lack' (9); it is only in the oblique subject construction that a modal meaning occurs: either a participant internal need, participant external necessity (deontic modality), or even epistemic modality. This conclusion is further corroborated by the fact that the middle déomai, which means 'be in want, require', implying control, acquires a deontic modal meaning of obligation in the oblique subject construction:

(14) deîtai oûn soi pálin ex

be.needful.3SG.PRES.MP therefore you.2SG.DAT again from

arkhês... tês autês erōtéseōs

beginning the.GEN same.GEN questioning.GEN

'Therefore you must face the same question ... from the beginning again' (Plat. Meno. 79c)

As example (14) shows, as soon as the middle déomai occurs with an oblique subject construction, it receives a modal sense. This suggests that the construction itself has an autonomous meaning that is imposed on the lexical elements that instantiate the construction.

4.1.2 khré (estí)

The compositional predicate $k h r e ̂ ́(e s t i ̂)$ is widely documented in Herodotus, Sophocles, Aristophanes, and Aeschylus. It is always used impersonally, and it is attested in two different morphosyntactic frames: with an accusative subject and a genitive object, as in (15a), and with an accusative subject and an infinitive, as in $(15 \mathrm{~b}-16)$.

(15) a. ou mén se khrè̀ ét' aidoûs

not indeed you.2SG.ACC necessity further awe.GEN

'You do not need to feel awe any further' (Hom. Od. 3.14)

b. oudé tí se khrè / nēleès êtor not.even what you.2SG.ACC necessity ruthless.ACC heart.ACC ékhein

have.INF

'You do not need to have a ruthless heart at all' (Hom. Il. 9.497)

This predicate can express need, as in examples (15a-b). In (15a), Telemachus, who is looking for his father without finding him, is told by Athena that he does not have to feel awe, but instead must go straightaway to ask Nestor if he knows 
something about his father. In (15b), Achilles is told that he does not need to be pitiless since even the very gods can bend.

The predicate khré (estí) can also express obligation, as in example (16), where Mardonius tells Xerxes that he must deliver Hellas, enslaved, to him.

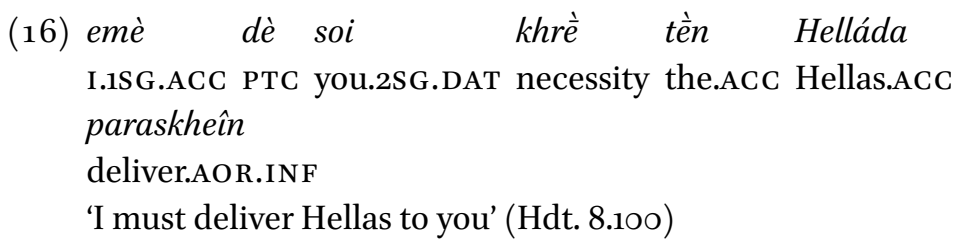

An issue worthy of further exploration is the role of verbal polysemy with regard to, for instance, different types of necessity (moral obligation, need, etc.), and whether and how it may affect argument structure constructions. This, however, lies outside the scope of the present article.

\title{
4.1.3 epanaménei
}

The verb epanaménō in the nominative subject construction means 'wait (longer)':

(17) mà Dí all' epanameínōmen olígou

PTC thus but wait.1PL.SBJV little

'But let us wait for a little longer' (Aristoph. Lys. 74)

However, in the oblique subject construction, with an infinitive and a dative (18a) or an accusative subject (18b), deontic modality is expressed. The oblique subject construction is documented in Sophocles and Aeschylus, with two examples from Aeschylus below:

\author{
(18) a. sphin kakôn húpsist' epamménei \\ they.3PL.DAT bad.GEN highest.ACC be.fated.3SG.PRES \\ pathein \\ suffer.AOR.INF \\ 'They are fated to suffer the worst of the disasters' (Aesch. Pers. 807) \\ b. $t^{\prime} \quad m^{\prime}$ epamménei patheîn \\ what I.1SG.ACC be.fated.3SG.PRES suffer.AOR.INF \\ 'What am I fated to suffer?' (Aesch. Pers. 807)
}


4.1.4 ménei

The verb ménō in the nominative subject construction means 'stay, remain':
(19) hốs te stélè
ménei
émpedon

like and block.of.stone.NOM stay.3SG.PREs fast

'It stands fast as a block of stone' (Hom. Il. 17.434)

In addition, this verb is documented in the meaning 'wait for', which is naturally derived from the meaning 'stay', also in the nominative subject construction:

\section{(20) hós Danaoi Trôas ménon émpedon oudè thus Danaans.NOM Trojans.ACC wait.3PL.IPFV firmly and.not phébonto}

flee.3PL.IPFV

'Thus the Danaans waited firmly for the Trojans and did not flee' (Hom. Il. 5.527)

In the oblique subject construction with an infinitive and a dative subject, the verb ménō expresses deontic modality instead. This construction is found in Aeschylus and Euripides, with an example from Euripides below:

(21) toîs pâsin anthrốpoisi katthaneîn ménei

the.DAT all.DAT men.DAT die.AOR.INF wait.3SG.PRES

'All men must die' (Eur. Fragments 733, Stob. Flor. 124. 29)

\subsection{5 opheílei}

The verb opheilei in the nominative subject construction has the meaning 'be debtor of, owe, have to pay':
(22) phér'
ido
tí opheílo;
dódeka

bear.2SG.IPFV see.1SG.AOR.SBJV what owe.1SG.PREs twelve

mnās Pasíāi

minas.NOM Pasias.DAT

'Come, let me see; what do I owe? Twelve minas to Pasias.'

(Aristoph. Cl. 21)

This verb expresses a duty since it is used when someone is indebted to someone else and has to give payment to that person. This meaning 'owe' is thus close to the semantics of modals, and in fact there are some cases in which 
the nominative subject construction indeed conveys the idea of obligation, as in (23) below:

(23) all'óphelen athanátoisin / eúkhesthai

but owe.3SG.AOR immortals.DAT pray.INF

'But he ought to offer prayers to the immortals.' (Hom. Il. 23.547)

The semantic extension from the meaning of having to pay something, i.e. 'to owe', to the expression of duty is unsurprising (see Ruiz Yamuza 2008). However, there is an important difference between the use of the verb in the nominative vs. the oblique subject construction; basically, as shown by the examples above, in the nominative subject construction both readings (the pre-modal and the modal one) are possible; it is the pragmatic context that clarifies which one is the relevant one. In the oblique subject construction, however, such ambiguity is not found.

The verb opheilei in the oblique subject construction has a pure modal function; it always conveys a general deontic meaning of obligation. The oblique subject construction is documented with the accusative and the infinitive, e.g. in Pindar and Apollonius Rhodius, as illustrated in (24) below.

(24) óphellé me mête tokêōn/ dôma tód' owe.3SG.IPFV I.1SG.ACC and.not parents.GEN house.ACC this.ACC eisoráan

behold.ACC

'I should not have beheld this house of my parents' (Apollon. 3.678-679)

Moreover, an oblique subject may also occur with middle forms of the verb as found in Sophocles, Euripides, and Lysias and exemplified in (25).

(25) hōs pâsin hēmîn katthaneîn opheíletai

that all.DAT US.DAT die.AOR.INF OWe.3SG.PRES.MP

'That we all must die' (Eur. Alc. 419)

As example (25) shows, when the verb appears in an oblique subject construction, even with the mediopassive morphology, it indicates participant-external necessity. In other words, the oblique subject construction is so entrenched in the linguistic system of Ancient Greek that both the active and the middle verbal forms are found in it, and independent of grammatical voice, the same meaning is found in both cases, clearly imposed by the oblique subject construction itself. 
4.1.6 prépei

The verb prépei in the nominative subject construction is primarily a verb of perception; it is related to impressions of the senses and means 'to be clearly seen (with the eyes); to sound clear (to the ears); to be strong (in smell)'. It can also mean 'to be conspicuously like, to be conspicuously fitting', as in (26).
(26) thnatà
thnatô̂si prépei
mortal.things.NOM mortals.DAT fit.3SG.PRES
'Mortal things are appropriate for mortal men' (Pi.I.5(4).16)

It is probably this meaning of 'fit, be appropriate' that licenses the modal meaning also found with this verb. This modal meaning is documented with an oblique subject construction expressing obligation. Both an accusative subject, with and without an infinitive as in (27a-b), and a dative subject, as in (27c), are attested.

(27) a. prépei goûn soi [apokrínesthai]

be.fitting.3SG.PRES certainly you.2SG.DAT answer.INF.MP

'It certainly fits you to answer' (= 'You should answer') (Xen. Hell. 4.1.37)

b. hoútō hōs keínous éprepe

so as those.ACc be.fitting.3SG.IPFV

'So as they deserved' (Hdt. 8.68A)

c. hōs prépei doúlois légein

as be.fitting.3SG.PRES slaves.DAT speak.INF

'As it suits slaves to speak.' (= 'as the slaves should speak')

(Eur. Hipp. 115)

In (27a) the duty of answering depends on the judgment of the speaker, in $(27 \mathrm{c})$ on social conventions.

4.1.7 harmózei

The verb harmózei in its basic Dat-Nom construction means 'fit, fit well; be fitting'.
(28) âr' harmosei moi
(i.e. $t a \grave{~}$
hupodémata)?
PTC fit.3sG.FUT I.1SG.DAT
the.NOM slippers.Nom
'Will they (i.e. the slippers) fit me?' (Aristoph. Thes. 263) 
In the accusative subject construction, however, the same verb expresses deontic modality. The accusative subject construction is documented in Homer, Sophocles, Demosthenes, and Isocrates, with an example from Sophocles below:

(29) sigān àn harmózoi se

be.silent.INF PTC fit.3SG.OPT you.2SG.ACC

'You should be silent' (Soph. Trach. 731)

4.1.8 epéoike

The perfect form epéoike means 'suit' in its basic Nom-Dat construction, as shown in $(30)$ below.

(30) hós tis hồ t' epéoike

RP.NOM someone.NOM him.3sG.DAT and suit.3SG.PFV

'Someone who could be fitting for him' (Hom. Il. 9.392)

However, this verb mostly occurs in the oblique subject construction, documented with both a dative subject (31a) and an accusative subject (31b), expressing deontic modality. Both the dative and the accusative subject constructions are attested in Homer, with two examples below:
a. sphön mén t' epéoike...
hestámen
you.2DU.DAT PTC and be.proper.3SG.PFV stay.PFV.INF
'You two were better to stay ...' (Hom. Il. 4.341-342)
b. hón t' epéoike boulàs bouleúein
RP.ACC and be.proper.3SG.PFV counsels.ACC decide.INF
'And whomsoever should take counsel' (Hom. Il. 10.146-147)

4.1.9 anánkē (esti)

The predicate anánkē (esti) with the infinitive means 'it is necessary'; anánkē itself is a noun meaning 'necessity'. This predicate can take a dative subject, expressing deontic necessity 'must'. This predicate is documented in Herodotus, Aeschylus, and Lysias, with examples from Aeschylus and Herodotus below:
(32) a. anánkē
tôndé
moi
tólman
skhetheîn
necessity.NOM these.GEN I.ISG.DAT courage.ACC have.INF 'I must get the courage for this deed' (Aesch. $P B$ 1.16) 
b. tréphein toùs tokéas toîsi mèn paisi oudemía feed.INF the.ACC parents.ACC the.DAT PTC sons.DAT any.NOM anánkē mè bouloménoisi necessity.NOM not want.PRES.MP.PART.DAT

'Sons must not support their parents if they do not want to' (Hdt. 2.35)

4.1.10 méllei

The verb méllei in the nominative subject construction occurs with two different meanings; the first is 'be about (to do something)' with an inceptive reading, while the second meaning indicates an estimated certainty or strong probability in the present, past, or future, specifically, 'be destined, likely to'. This verb therefore can be considered to have an epistemic function, since it expresses the confidence of the speaker in the truth of the content of the utterance.
(33) keleusémenai dé $s^{\prime}$
émelle /
daímōn
urge.FUT.INF PTC you.2sG.ACc be.likely.3sG.IPFV deity.NOM
'A deity must surely have urged you' (Hom. Od. 4.274)

This verb, méllei, moreover, is occasionally documented in Homer in an oblique subject construction with a dative subject and an infinitive. In the dative subject construction, it always has a modal function:
(34) ei d' oútō toût' estin emoi méllei phílon eînai
if PTC so this.NOM be.3sG.PRES I.1SG.DAT be.about.to.do.3SG.PRES
pleasant be.INF
'If this is as you say, then I must be pleased' (Hom. Il. 1.563)

The example in (34) above is part of a dialogue: Zeus replies to Hera that if the things are as she claims, then he must be pleased. As example (34) thus illustrates, méllei expresses epistemic modality.

After this overview of verbs in Ancient Greek that express necessity when they co-occur with oblique subjects, we turn to the expression of possibility.

\subsection{Possibility}

In Ancient Greek, different strategies are used to express possibility. The optative mood, with or without the particles ké or án, is one of them. 


\author{
(35) éloimí ken é ken haloiên \\ grasp.1SG.AOR.OPT PTC or PTC be.taken.1SG.AOR.OPT \\ 'I may slay or I may be taken' (Hom. Il. 22.253)
}

Ancient Greek also has a modal verb, namely, dúnamai 'be able', which typically occurs in the nominative subject construction and designates participantinternal possibility.
(36) Zeùs
dúnatai
hápanta
Zeus.NOM be.able.3sG.PREs everything.Acc
'Zeus can (do) everything' (Hom. Od. 4.237)

However, the expression of possibility is mainly expressed via oblique subject constructions in Ancient Greek. In fact, there are a number of predicates that acquire a modal meaning of possibility as soon as they enter into an oblique subject construction. Each of these predicates are analyzed in turn in the following subsections.

\title{
4.2.1 dúnatai
}

The verb dúnamai expresses the subject referent's ability to carry out an event, as shown in (36) above. However, when this verb enters into an oblique subject construction, a participant-external possibility is expressed instead, as in (37).

(37) toîsi Spartiétēisi kallierêsai

the.DAT Spartans.DAT obtain.good.omens.AOR.INF

thuoménoisi ouk edúnato

sacrifice.PRES.PART.MP.DAT not be.able.3SG.IPFV

'The Spartans were not able to obtain good omens when they offered sacrifices' (Hdt. 7.134)

In this passage, Herodotus explains that the Spartans were not able to get good omens when they offered their sacrifices, due to an accident after which they became unlucky. This means that the capability of the subject referent is not determined by their own abilities but rather by the circumstances found in this particular context.

4.2.2 énesti

In the nominative subject construction, the verb énesti means 'be in a place'. 

(38) oíkoi énesti góos
at.home be.in.3SG.PREs lamentation.NOM
'There is lamentation at home' (Hom. Il. 24.240)

In the oblique subject construction, the verb énest is occasionally documented in Sophocles and denotes epistemic possibility, as shown in (39) below:

(39) énesti toîsin ê̂ skopouménois

be.possible.3SG.PRES the.DAT well consider.PRES.PART.MP.DAT

tarbein tòn êu prássonta

tremble.INF the.ACC well achieve.PRES.PART.ACC

'Those who look afar may fear for him who prospers' (Soph. Trach. 296)

Deianeira, the wife of Heracles, utters this sentence. She is here discussing her husband's fortune, and she observes, when thinking about the future, that one might worry that someone who succeeds one day can fail the next day.

4.2.3 éxesti

The verb éxesti occurs only impersonally in the oblique subject construction; it can combine with an infinitive and a dative subject as exemplified in (4Oa-b), or an accusative subject as shown in (4Oc).

(40) a. ássa dé sphi poièein ouk éxesti anything.ACC PTC they.3PL.DAT do.INF not be.allowed.3SG.PRES taûta oudè légein éxesti these.ACC not.even speak.INF be.allowed.3SG.PRES 'Of what they are not allowed to do, they are not allowed to speak, either' (Hdt. 1.138)

b. éxesti

gár moi mè légein à

be.allowed.3SG.PRES indeed I.ISG.DAT not say.INF which.NOM $m \overline{\grave{e}}$ telô

not accomplish.1SG.FUT

'Indeed I cannot promise what I will not accomplish' (Aesch. Eum. 899)

c. oud' éxesti basiléa ... árkhein khōris

not be.allowed.3SG.PREs king.ACC be.first.INF apart

hieratikês

priestly.GEN

'No king ... can rule without being a priest' (Plat. Stat. 29od) 
The oblique subject construction thus expresses deontic modality of permission with the verb éxesti. It is documented in Herodotus, Aeschylus, Sophocles, Thucydides, Xenophon, and Plato.

\subsection{4 pareíkei}

The verb pareikei, in the nominative subject construction, has various but related meanings. Basically, it means 'give way (to someone), permit a passage' and also 'allow'.

(41) hoîsper àn ho theòs pareíkēi

who.DAT PTC the.NOM god.NOM permit.3SG.PRES.SBJV

'All of them to whom the god gives permission ...' (Plat. Theaet. 15od)

In the oblique subject construction, the verb pareíkei has a modal function expressing deontic possibility.

(42) a. eí moi pareíkoi

if I.1SG.DAT allow.3SG.PRES.OPT

'If I were allowed (Soph. Phil. 1048)'

b. pareîkhe àn sphi eudaimonéein Hellếnōn provide.3SG.IPFV PTC they.3PL.DAT be.prosperous.INF Greeks.GEN málista

most

'They might have been most prosperous of all Greeks' (Hdt. 1.170)

The difference between the nominative subject construction and the oblique subject construction is that in the former it is the subject referent who gives permission, while in the oblique subject construction the subject referent has received permission to carry out an event.

\subsection{5 dunatôs ékhei}

The predicate dunatôs ékhei is formed by combining the adverb dunatôs 'strongly' and the verb 'have'; when it selects for a dative subject it expresses participant-external possibility:

(43) oúkōn exanakhōréein oudetéroisi dunatôs not.therefore retreat.INF neither.of.the.two.DAT strongly ékhei

have.3SG.PRES

'Therefore it is not possible for either of us to turn back' (Hdt. 7.11) 


\subsection{6 enkhōrêे}

The verb enkhōréō, when occurring in the nominative subject construction, means 'give room, allow', as shown in (44) below:
(44) ho
khrónos ouk enkhōrêे
állon
apoklērōsai
the.NOM time.NOM not allow.3SG.PREs another.Acc elect.AOR.INF
'That time does not allow electing another man' (Lys. 26 6)

In the oblique subject construction, however, with a dative subject and an infinitive, it expresses participant-external possibility:

(45) tôi dè Promēthề... oukéti enekhốrei

the.DAT PTC Prometheus.DAT anymore be.possible.3sG.IPFV

eiseltheîn

enter.INF

'Prometheus was not allowed to enter anymore' (Plat. Prot. 321d)

The oblique subject construction is documented in Plato, Lysias, and Antiphon.

\subsection{7 ekgígnetai}

The verb ekgígnomai means 'be born' when occurring in the nominative subject construction, as shown in (46).
(46) hoi
Diòs
exegénonto
who.NOM Zeus.Gen be.born.3PL.AOR
'Those who are born of Zeus' (Hom. Il. 5.637)

In the oblique subject construction with a dative subject and an infinitive, documented in Herodotus, Lysias, Aeschines, Isocrates, and Demosthenes, the meaning completely changes; it expresses participant-external possibility:
(47) apikoménoisi... kaì mathoûsi... ouk
arrive.AOR.PART.DAT and learn.AOR.PART.DAT not
exegénetó Kroisōi apaggeîlai

be.allowed.3SG.IPFV Croesos announce.AOR.INF

'Those arriving [to the prophetic ones] ... and learning [from the Telmessians what the portent meant] ... were not allowed to announce it to Croesos' (Hdt. 1.78) 


\subsection{8 hupárkhei}

The verb hupárkhō, when occurring in the nominative subject construction, means 'begin, come into existence, become, be'. However, in the oblique subject construction, documented in Plato, Andocides, Thucydides, Isocrates, and Sophocles with a dative subject and an infinitive, as in (48a), or with an accusative subject, as in (48b), it expresses modality.

\section{a. hupárkhei d' èmîn éti nûn ge tà}

be.possible.3SG.PRES PTC we.1PL.DAT even now and the.ACC

pleío tôi pezôi epikrateîn

more.ACC the.DAT land.force.DAT be.superior.INF

'And even now we may be superior with the land-force on the whole' (Thuc. 7.63)

\section{b. hupárkhei gár se mè gnônaí}

be.possible.3SG.PREs indeed you.2SG.ACC not know.AOR.INF

tina

anyone.ACC

'It is for sure that no one recognizes you' (Soph. El. 1340)

It is not self-evident how to identify which domain of modality is expressed with constructions formed with the verb hupárkhei; in fact, in (48a), external possibility is expressed: Nicias, seeing the depression of his soldiers, tries to encourage them and argues that it is still possible for them to count on the superiority of infantry. There are cases, however, like the one exemplified in (48b), where an epistemic interpretation is also plausible; in this passage, the paedagogus tells Orestes that when he enters his father's house, no one will recognize him. Here hupárkhei can mean both that people will not be able to recognize him and to indicate the certainty of the speaker that people will surely not recognize him.

\subsection{9 hoî́n (esti)}

The relative pronoun hoî́s 'what kind' with the verb 'be' in the nominative subject construction expresses capability.

(49) hotiè légein hoîos te kagō

because say.INF what.kind.NOM PTC and.1SG.NOM

'Because I know how to speak' (Aristoph. Kn. 343) 
This same relative lexeme is also documented in an oblique subject construction with a dative subject and an infinitive.

(50) mè̀ hoî̀n ge eînai taûta emoì kōlûsai

not possible.NOM.SG and be.INF this.ACC I.ISG.DAT prevent.AOR.INF tôi stratēgôi

the.DAT general.DAT

'Although I am the General, I cannot prevent these things' (Thuc. 7.14)

There is no doubt that a modal meaning is entailed in both the nominative and the oblique subject construction. The difference between the two is that in the nominative subject construction ability is expressed, while in the oblique subject construction the modal meaning is that of external possibility. As exemplified in (50), where the General states that it is not in his power to stop the disorders (for reasons which are not because of himself but because of the fact that tempters have access to more resources and forces than his crew), in the oblique subject construction, the possibility that the subject referent can act is totally dependent on external circumstances.

\section{5}

Nonmodal meaning and modal meaning

For the nominative subject construction, the verbs expressing necessity constitute a relatively homogeneous semantic class; they can basically be categorized into two subclasses: those that denote expectation (verbs meaning 'wait, expect, lack, owe'), and those that denote appropriateness (verbs meaning 'be fitting, be appropriate'). The predicates expressing possibility are also fairly homogeneous in the sense that they are mostly related to the conceptual domains of capability and allowance, as shown in Figure 2.

The semantics of modality and the development from the nonmodal meaning to the modal meaning that emerges from the overview above indeed confirms the adjacency relations in the semantic map proposed by van der Auwera \& Plungian (1998):

- Predicates meaning 'need' can express participant-internal necessity, participant-external necessity, and epistemic necessity.

- Predicates meaning 'be expected, supposed' can express participant-external necessity.

- Predicates meaning 'owe, be good, proper' can express participant-external necessity. 

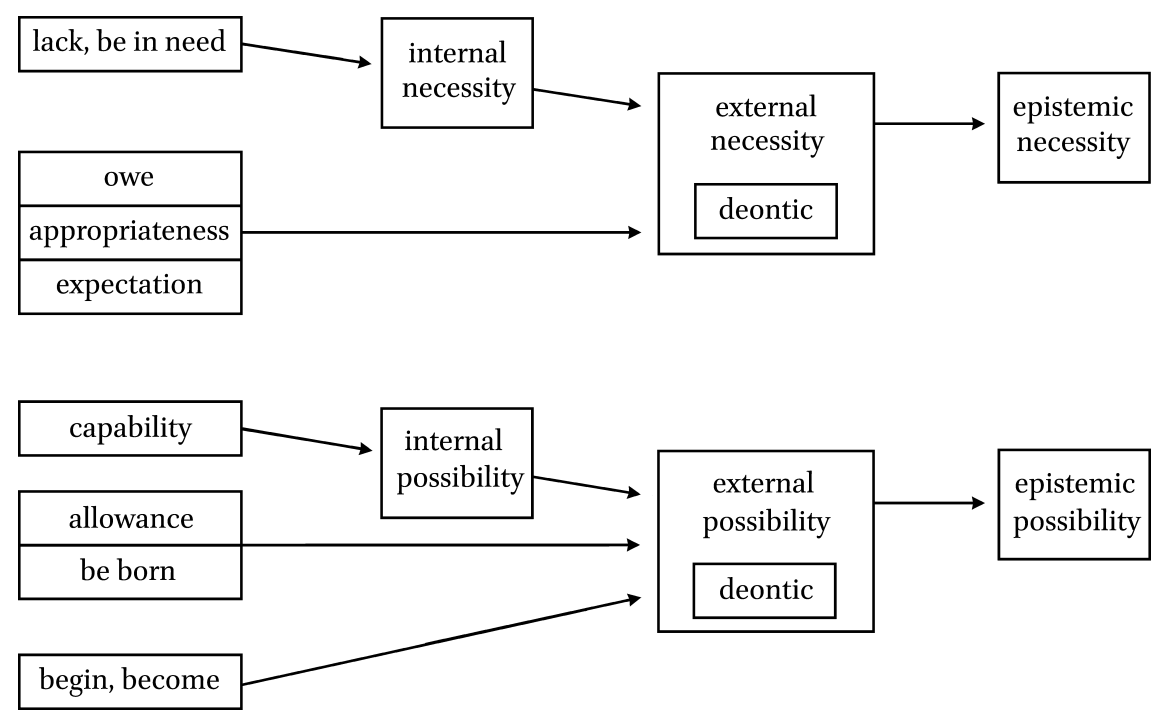

FIGURE 2 The conceptual domain of Ancient Greek modal verbs

- Predicates meaning 'be possible, be allowed' can express participant-external possibility.

The only possible discrepancy between the depiction of modality emerging from Ancient Greek and van der Auwera \& Plungian's map relates to verbs meaning 'become', which should be a source of only epistemic modality. Instead, in Ancient Greek, the verb hupárkhō 'begin, come into existence, become' designates permission as well as some epistemic values.

We now proceed to investigate the relation between the nonmodal and the modal meaning found for the Ancient Greek predicates discussed above. The analysis reveals that the semantic shift from one meaning to the other is not necessarily a matter of diachronic evolution, as suggested by Ruiz Yamuza (2008), but is rather a matter of differences in constructions and constructional choices.

\subsection{Predicate meaning and constructional meaning}

Most of the predicates that participate in the oblique subject construction may also instantiate the nominative subject construction. Thus, these predicates are compatible with different argument structure constructions and, depending on the construction-nominative or oblique subject construction-they also exhibit a different meaning. For example, the verb ménei 'wait for' can be constructed with a nominative subject and an accusative object, as in example (20) above, (repeated here as 51a), but it can also occur in an oblique subject con- 
struction, as exemplified in (21) above (repeated here as $51 \mathrm{~b}$ ), with an oblique subject and a complement clause.

(51) a. hốs Danaoì Trôas ménon émpedon oudè thus Danaans.NOM Trojans.ACC wait.3PL.IPFV firmly and.not phébonto

flee.3P L.IPFV

'Thus the Danaans waited firmly for the Trojans and did not flee' (Hom. Il. 5.527)

b. tô̂s pâsin anthrốpoisi katthaneîn ménei the.DAT all.DAT men.DAT die.AOR.INF wait.3SG.PRES 'All men must die' (Eur. Fragments 733, Stob. Flor. 124. 29)

The meaning of the construction in (51a), the Nom-Acc transitive construction together with the verb ménei 'waits for', is entirely transparent, i.e., 'the Danaans waited firmly for the Trojans', with 'Danaans' being in the nominative case and 'Trojans' in the accusative case. This is an example of general semantic interpretation rules applying to the lexical entities in (51a), resulting in the meaning of the whole amounting to the sum of the meaning of the parts (cf. Tomasello 1998: 481-482; Croft \& Cruse 2004: 235-254; Barðdal et al 2011: 86-96 on the distinction between general vs. specific semantics, also sometimes referred to as compositional vs. noncompositional semantics in the literature). There is thus no doubt that the meaning of the construction in (51a) is compositional, as it can easily be derived from the semantics of the parts.

In contrast, the modal meaning of the construction in (51b), the oblique subject construction with the verb ménei and an infinitive complement (DATINF-ménei), cannot be derived from the meaning of the parts, but must be noncompositionally derived. The infinitive verb has the meaning 'to die', the subject is in the dative case (tồs pâsin anthrốpoisi 'all men'), while the verb is the aforementioned 'waits for'. The literal meaning of the example in ( $51 b)$ is therefore 'all men wait to die', which, however, is not the meaning that we find in ( $5 \mathrm{lb})$, where the verb rather designates obligation 'must'. The meaning 'must' is only found with ménei when used in the DAT-INF-ménei construction and must thus be attributed to the DAT-INF-ménei construction itself. The same is true for most of the modal uses of the verbs listed in Section 4 above.

The question now arises whether the modal meaning in (51b) stems from this particular dative or perhaps from the category of datives in general. Clearly the lexical meaning of the dative in (51b), 'all men', cannot be responsible for the 'must' meaning found with the verb when it occurs in the DAT-INF-ménei 
construction. Moreover, assuming a direct link between the category of dative and the modal meaning would be problematic, because, as has been shown in Section 4 above, the dative can occur with different subsets of modal meanings, making it impossible to know which of these is associated with the dative in (48b) unless it is attributed to this particular verb-specific construction itself.

While oblique case marking of subjects is not unknown with modal verbs (Onishi 2001, Barðdal et al. 2012, Grillborzer 2014), there is nothing inherent in the concept of modality that in principle motivates a noncanonical argument structure. In fact, verbs like deō 'lack', harmózō 'fit well', epéoike 'suit', epanaménō 'wait for', ménō 'stay where one is (intr.), wait for (tr.)', opheílō 'owe, have to pay', and prépo 'be clearly perceived' regularly profile the initiator of the verbal event (which can be an agent, an experiencer, or a stimulus) as a nominative subject and the goal as a dative, genitive, or accusative object. This shows, therefore, that the modal meaning of these predicates cannot be compositionally derived. One could perhaps argue that the modal meaning is a metaphorical extension of these predicates' lexical meaning (cf. Ruiz Yamuza 2008), which is possible, but this does still not explain the link between an oblique subject (used in place of a nominative one) and the modal function.

Indeed there is no special feature of the verb structure by which the combination of a predicate with a third person verbal form and the consequent modal meaning may be predicted. Despite that, in Ancient Greek, this is a conventional way to express modality, indicating that this syntactic structure, the oblique case marking of the subject, and the general meaning of modality associated with this structure, is a stored pattern and licenses a set of actual constructs in Ancient Greek. Hence, the oblique case marking is an integral part of a larger unit, namely the argument structure construction which exists irrespective of these modal predicates as a larger construction in Ancient Greek.

Moreover, there is nothing that suggests that the link between the nonmodal meaning and the modal meaning depends on diachronic evolution; this is clearly shown by the fact that in the same Ancient Greek text, it is possible to find one and the same verb used both in the nominative subject construction with the nonmodal meaning 'begin', as in (52a), and with the modal meaning 'can' in the oblique subject construction, as in ( $\left.5^{2 b}\right)$.

(52) a. kai oi Lakedaimónioi hupērxan

and the.NOM Lakedaemonians.NOM begin.3PL.AOR

'And the Lakedaemonians started it' (Thuc. 2.67)

b. hupárkhei d' hēmîn éti nûn ge tà be.possible.3SG.PRES PTC we.1PL.DAT even now and the.ACC 
$\begin{array}{llll}\text { pleío } & \text { tôi } & \text { pezôi } & \text { epikrateîn } \\ \text { more.ACC } & \text { the.DAT land.force.DAT } & \text { be.superior.INF }\end{array}$

'And even now we may be superior with the land-force on the whole' (Thuc. 7.63)

Indeed, if the argument structure is considered to be derived from the sole (literal) meaning of the verb, most of the verbs in Section 4 above-with the exception of those which only have an impersonal use-should be expected to profile a canonical structure with a nominative subject and, in case they are transitive, an accusative, dative, or genitive object.

In contrast to the nominative subject construction-which is compositional, containing predicates exhibiting a lexical meaning - the oblique subject construction is idiomatic to a certain extent, in that the modal meaning cannot be derived from the individual lexical or grammatical items instantiating this subconstruction of the oblique subject construction. In other words, since the meaning of the whole cannot be derived from the meaning of the parts, the meaning of modality with the oblique subject construction must be regarded as a property of the construction itself.

The oblique subject construction with its modal meaning can be formalized as in Figure 3, in the spirit of Radical Construction Grammar (Croft 2001, Barðdal 2006, Fischer \& Alm 2013), where the construction as a whole is regarded as the primitive unit of language, while the individual parts of each construction are regarded as derivatives of that same whole. In essence, this means that the meaning of the parts is derived from the meaning of the whole. Figure 3 is a formalization of the concrete verb-specific oblique subject construction with epamménei 'be fated to' selecting for a dative subject and an infinitive, already presented in (18a) above, repeated here as (53):

\section{(53) sphin}

kakôn húpsist'

epamménei

patheîn

they.3PL.DAT bad.GEN highest.ACc be.fated.3SG.PRES suffer.AOR.INF

'They are fated to suffer the worst of the disasters' (Aesch. Pers. 807)

The upper field in Figure 3 represents the syntactic component of the DATepamménei-INF construction, while the lower field represents the semantic elements of the construction. The dotted lines between the components in the SYN field and the elements in the SEM field represent the symbolic links between the two. It is clear from Figure 3 that the verb epamménei can indeed be regarded as having a compositional meaning; it just so happens that this meaning is specific to this particular construction, hence a constructional account is needed. The representation in Figure 3 contains, in addition to the 


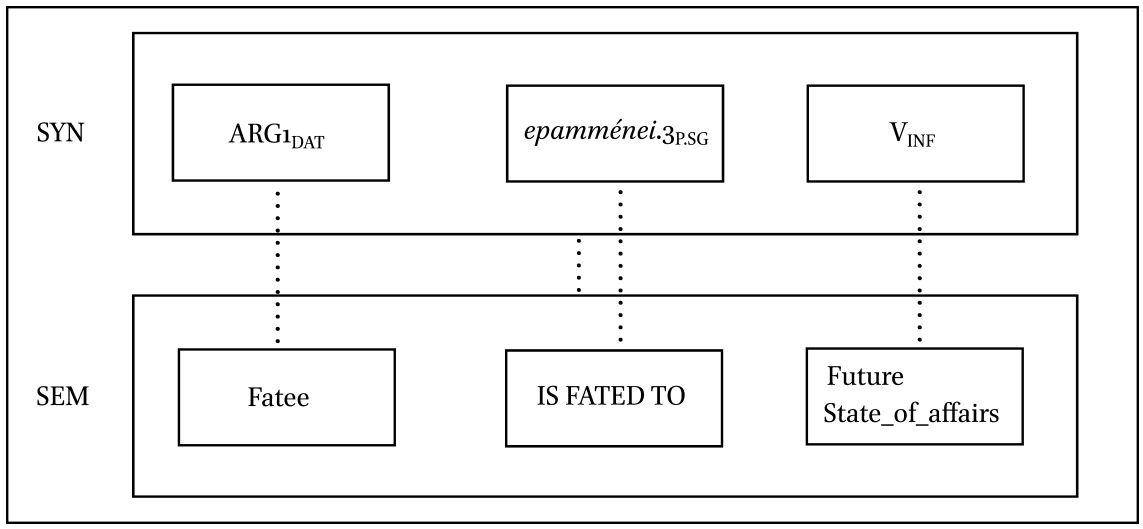

FIGURE 3 A formal representation of the DAT-epamménei-INF modal construction

three symbolic links between each of the SYN components and each of the SEM elements, a further symbolic link between the SYN and the SEM fields as a whole. This is how the mapping between regular syntax and irregular or specific semantics is captured with the constructional formalism.

Croft (2001: 179-185) argues, following Nunberg et al. (1994) for examples equivalent to our example with epamménei 'waits for' vs. 'is fated', that such examples can indeed be considered semantically compositional, since the modal meaning can be attributed to the verb epamménei itself. However, such examples are still semantically irregular since epamménei only has the meaning 'is fated' in this particular construction, not found with any other argument structure. The relevant semantic interpretation rules are thus unique for this construction, again warranting a constructional analysis for the oblique subject construction with a modal meaning in Ancient Greek.

Returning to the issue of diachronic development, it is of course possible, though not a given, that the modal meaning is historically derived from the meaning of the verb found in the nominative subject construction, as suggested by Ruiz Yamuza (2008). However, if the modal meaning continues the old meaning, one would expect the new meaning simply to occur with the same argument structure construction as the old meaning, which is not the case. The modal meaning of the predicates listed in Section 4 above is generally not found in the nominative subject construction (at least not the same modal meaning), but is found in a different argument structure construction, with a dative subject and an infinitive complement. Clearly, more research is needed on the diachronic evolution of modal constructions and their historical relation with their nonmodal counterparts in Ancient Greek. This historical relation, however, falls outside the scope of the present article, as the attested 
synchronic mapping of (mostly) nonmodal meanings and modal meanings onto the nominative vs. the oblique subject construction, respectively, is sufficient to motivate a constructional analysis for the synchronic grammar of Ancient Greek.

We now proceed to provide a motivation for the meaning of modality with oblique subject constructions.

The oblique subject construction, modality and subjectification

Subjectivity as a concept is expressed linguistically when the speaker shows a specific attitude towards the content of an uttered clause (cf. Hanson 1987; Traugott 1989, 1995, 2003; Sweetser 1990; Hopper \& Traugott 1993; Paradis 20o1; Traugott \& Dasher 2002). The speaker's perception of the event can be indicated through linguistic means like modality or evaluative phrases like hopefully in Hopefully, John will catch the bus, and apparently in Apparently, this kid is awesome. Subjectification itself is a process in which the pragmatic level of speech is grammaticalized; it codifies the speaker's attitude towards the event described such that the speaker's perspective becomes an integral part of the speech and is expressed with specific grammatical means.

Traugott (2003: 126) defines the notion of subjectivity as follows:

... the mechanism whereby meanings come over time to encode or externalize [Speaker]/[Writer]'s perspectives and attitudes as constrained by the communicative world of the speech event, rather than by so-called real world characteristics of the event or situation referred to.

The notion of subjectification has shown itself useful when explaining a set of diverse linguistic phenomena, including modality (cf. Allan 2013 on modality in Ancient Greek). The concept of subjectification has also been applied to the category of noncanonically case-marked subjects, which is particularly relevant for the present study. Barðdal (2004) invokes the notion of subjectification in order to explain the subject case marking of a special class of oblique subject predicates. She divides oblique-subject case marking into two categories. First is the category in which noncanonically case-marked subjects may be regarded as being determined by the semantics of the predicate with verbs expressing emotions, attitudes, cognitive abilities, perception, and bodily states, as the example in (54) illustrates. 
(54) Modern Icelandic

Mér líkar pessi bók

I.ISG.DAT likes.3SG this.NOM book.NOM

'I like this book.' (Barðdal 2004: 108)

In fact, the oblique subject can be analyzed as an experiencer motivated by the affectedness denoted by the verb, as well as by the low degree of control and volition (cf. also Barðdal \& Eythórsson 2009); in such a case the semantics of the dative subject and the semantics of the verb can be said to coincide.

However, dative subjects can also occur with predicates that cannot be analyzed as experience-based predicates. This is, indeed, Barðdal's (2004) second category of verbs instantiating the oblique subject construction, labeled performance predicates:

(55) Modern Icelandic

Honum talaðist vel

he.3SG.DAT speak.REFL.3SG.PAST well

'He gave a good speech.' (Barðdal 2004: 126)

But in this case, the oblique subject is clearly not determined by the semantics of the predicate, at least not on the assumption that dative subjects are prototypically experiencers.

According to Barðdal (2004), two different relations determine the shape of the argument structure. In addition to the semantic relation holding between the referent and the event denoted (like with lika 'like' in 54 above), the case marking of the subject can also be analyzed as deriving from the speaker's subjective attitude towards the content of the proposition. The latter relation is responsible for the dative marking of subjects with verbs of performance, as in (55) above. The subject of such verbs is not an experiencer at all; the subject is instead someone performing an event, which is evaluated in a certain way by the speaker. Compare the following three examples from Icelandic, one with a nominative subject (56a) and the other two with a dative subject (56b-c) of tala 'speak' vs. talast 'speak', respectively (from Barðdal 2004:126). Note that talaðist in $\left(55^{-56)}\right.$ occurs with a reflexive suffix and a manner adverb 'well' (see also Papangeli 2004 on such constructions in languages that have voice suffixes).

(56) Modern Icelandic

a. Hann talaði vel, fúslega.

he.3SG.NOM speak.3SG.PAST well willingly

'He gave a good speech, willingly.' 
b. *Honum talaðist vel, fúslega.

he.3SG.DAT speak.REFL.3SG.PAST well willingly

Intended meaning: 'He gave a good speech, willingly.'

c. *Honum talaðist

he.3SG.DAT speak.REFL.3SG.PAST

Intended meaning: 'He spoke.'

All examples in (56) express the same event, namely the one where the subject referent is giving a speech. The manner adverb vel 'well' here qualifies the verbal event tala 'speak' indicating that the speech event was a successful one. This manner adverb is obligatory as is evident from a comparison between (55) and (56c). The examples in (56a-b) differ in two respects: the case marking of the subject, nominative in (56a) and dative in (56b), and the presence vs. absence of the reflexive suffix of the verb. Yet the former example is grammatical while the latter is ungrammatical.

The explanation suggested by Barðdal (2004) is based on the concept of subjectification. She argues that $(56 \mathrm{~b})$ is ungrammatical because the dative subject inherently denotes the stance of the speaker, hence it cannot co-occur with subject-oriented adverbs like fúslega 'willingly', as such adverbs express the judgments of the subject referent. In other words, it is the speaker who is the experiencer in (56b), while in (54), with verbs like lika 'like', it is the subject referent that is the experiencer. Therefore, the ungrammaticality of examples like (56b) corroborates the analysis that the dative case depends on the judgment of the speaker and cannot be that of the subject referent's (for further examples of case markers being involved in the process of subjectification, see Chelliah 2009 and Sadler 2009).

Examples of this type are not confined to Modern Icelandic but are also known from other Indo-European languages, like Modern Polish (see Dąbrowska 1997:44-45):

(57) Modern Polish

a. Spato mi się dobrze. sleep.1SG.PAST I.1SG.DAT REFL well 'I slept well.'

b. *Spato mi się. sleep.1SG.PAST I.1SG.DAT REFL Intended meaning: 'I slept.' 


\section{(58) Modern Polish}

a. Piotrowi pracowato się dziś bezt rudu.

Peter.DAT work.3SG.PAST REFL today without difficulty

'Peter worked without difficulties today.'

\section{b. *Piotrowi pracowato się.}

Peter.DAT work.3SG.PAST REFL

Intended meaning: 'Peter worked.'

Exactly like in Icelandic, the evaluative complement is obligatory together with a dative subject(-like argument) and a reflexive form of the verb, again supporting the analysis that performance verbs occurring in the oblique subject construction express an evaluation, namely that of the speaker.

Similar to the situation of oblique subjects with performance verbs, we argue that the oblique subject of modal verbs is also motivated by the speaker's attitude towards the content of the utterance; such an attitude can be determined either by the speaker's own opinion or by some social, religious, or moral authority.

The oblique argument of Greek modal verbs is the subject, not only in the syntactic sense as discussed in Section 2.2 above, but also in the sense that it is the active part of the relation; in fact, it is the animate sentient entity that has to perform the event denoted by the nonfinite verb. However, this subject is not a prototypical one; it is not agentive and it does not control the event, and in one sense it is similar to an object since it is affected by the speaker's judgment or by social conventions.

The noncanonical marking of the subject is therefore clearly motivated by the semantic and pragmatic features of the event. Thus, it is not surprising that an oblique subject is used in modal contexts, since a modal event shares semantic characteristics, like the low degree of agency and volition, with events designated by predicates of emotion, bodily states, perception, etc. (cf. Barðdal 2004, Barðdal et al. 2012, Barðdal \& Eythórsson 2009). Indeed, in Ancient Greek, oblique subjects are also found with such types of events, as shown in (59), where the oblique subject occurs with an experience-based predicate.

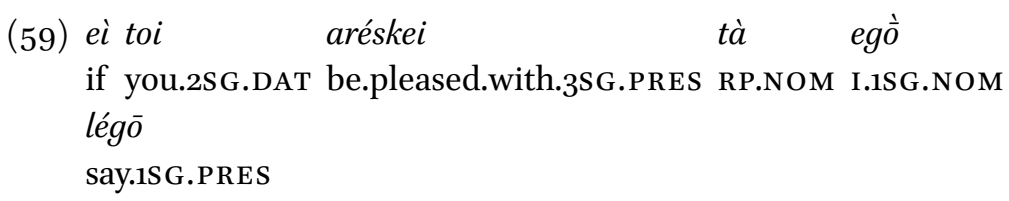

'If you like what I say' (Hdt. 1.89) 
In example (59), the predicate occurring with a nonnominative subject clearly signals affectedness of the subject referent in an experience-based event. In the same way, in modal expressions the case marking of the oblique subject indicates that the referent of that argument is subjected to the event without taking a fully active part in it. Affectedness is therefore the semantic link between these diverse types of events, but in the case of the experiencebased event, affectedness depends on the semantic relation involving the arguments and the predicate, while in a modal event, it depends on the empathic relation holding between the speaker and the event being expressed.

\section{Conclusions}

The present article has dealt with Ancient Greek expressions of modality by means of oblique subject predicates. Following the semantic map model proposed for modality by van der Auwera \& Plungian (1998), we have analyzed and classified several such Ancient Greek predicates into different modal categories. We have investigated the basic meaning of the predicate, the number, and the features of the arguments each predicate profiles, and the argument structure constructions in which these predicates occur.

As a result, we have shown that the modal meaning of these predicates is truly a constructional meaning, as it cannot be semantically derived from the meaning of the lexical items involved, but rather derives from the construction in which these modal predicates occur. In that sense, the meaning of the modal predicates can be regarded as compositionally derived, but only on the assumption that the semantic interpretation rules for the relevant constructions are indeed irregular, resulting in specific semantics as opposed to general semantics. Indeed most of these modal predicates have alternative syntactic uses; they appear also in personal structures with a nominative subject, but it is only in the oblique subject construction that a modal event is designated. Structures with modal predicates in the third person singular and a dative or an accusative subject can be considered instantiations of an oblique subject construction; the relation between the nonmodal meaning and the modal meaning of the predicate is not a matter of diachronic semantic change but represents a systematic synchronic alternation, depending on the construction. As such, a constructional analysis is called for in the synchronic grammar of Ancient Greek.

Generally, it is assumed that oblique subjects are experiencers in the world's languages, while we have argued that the oblique subject construction with a modal meaning in Ancient Greek is pragmatically motivated, involving a pro- 
cess of subjectification by which the speaker's attitude towards the event is grammaticalized. Hence, the oblique subject construction with a modal meaning provides a linguistic expression to the speaker's perspective that becomes an integral part of the event.

It is well known that the oblique subject construction is generally used to signal affectedness of the subject. In Ancient Greek, oblique subjects usually occur with predicates expressing different types of experience-based events, involving a nonprototypical transitive relation where the oblique argument denotes an atypical subject. Such a nonprototypical transitive relation is also found with oblique subject constructions with a modal meaning. The subject is an affected participant in the situation, affected either by the speaker's judgment or by some social or moral conventions. This similarity between the nonprototypical transitive relation found with experience-based predicates and modal predicates motivates the oblique case marking found across these two subtypes of oblique subject constructions.

\section{Appendix: list of modal predicates}

\section{deî}

hótōi dè kaì dề pharmákōn

anything.which.DAT PTC and be.needful.3SG.PRES medicines.GEN paiōníōn

Paionian.GEN

'anything which needs the Paionian medicines' (Aesch. Ag. 848)

See also exx. $6 b, 11 a, 11 b, 12 a, 12 b$, and 14.

dề s'hópōs patròs/ deíxeis en

be.needful.3SG.PRES you.2SG.ACc.that father.GEN prove.2SG.FUT in ekhtrô̂s

enemies.DAT

'you must prove among your father's enemies' (Soph. Aj. 556)

édei gàr sè tautà poieîn tồs állois

be.needful.3sG.IPFV for you.2sG.ACC this.ACC do.INF the.DAT other.DAT triērárkhois

trierarchs.DAT

'you had to do these things as the other trierarchs' (Dem. $5^{\circ} 35$ ) 
eí ti déoi tôi khorôi

if something.NOM be.needful.3SG.OPT the.DAT chorus.DAT 'if the chorus would need something' (Antiph. 6 12)

\section{khrế (estí)}

See also exx. $15 b$ and 16 .

ou mén se khrè̀ ét' aidoûs

not indeed you.2SG.ACC necessity further shyness.GEN

'You do not need shyness any further' (= 'you should not feel shy any further') (Hom. Od. 3.14)

hótteó se khré

anything.which.GEN you.2SG.ACC necessity 'anything of which you have need' (Hom. Od. 1.124)

\section{epanaménei}

See exx. $18 a(=53)$ and $18 b$.

\section{ménei}

See exx. 21 and 516 .

\section{opheílei}

See also exx. 24 and 25.

soì... toût' opheiletai patheîn you.2SG.DAT this.ACC Owe.3SG.PRES.MP suffer.AOR.INF 'you are doomed to experience this' (Soph. Ph. 1421)

$$
\text { prépei }
$$

See exx. 27a, 27b, and $27 c$.

\section{harmózei}

See also exx. 29.

oúte gàr harmóttei moi thugatéra epígamon not for fit.3SG.PRES 1.1SG.DAT daughter.ACC marriageable.ACC ékhonti oikeîn metà toioútōn have.PRES.PART.DAT dwell.INF with these.GEN 'I should not dwell with these sorts of men, having a daughter of marriageable age' (Dem. 40 57) 


\section{epéoika}

See exx. 3ra and 316 .

anánkē (estí)

See also exx. $32 a$ and $32 b$.

nûn oûn humîn en anánkē estì

now certainly you.2PL.DAT moreover necessity.NOM be.3SG.PRES

'Now moreover you must deliberate regarding this' (Lys. 6 8)

$$
\text { méllei }
$$

See ex. 34 .

\section{dúnatai}

See also ex. 37 .

\section{énesti}

See also ex. 39 .

tônd' árnēsis ouk énesti moi

these.GEN denial.NOM not be.possible.3SG.PRES I.1SG.DAT

'I cannot deny this' (Soph. El. 527)

(eí) Khálkeon dé moi êtor eneíe

if of.bronze.NOM PTC 1.1SG.DAT heart.NOM be.in.3SG.OPT

'if I had a heart of bronze' (Hom. Il. 2.49o)

\section{éxesti}

See also exx. 40a, 4ob, and $40 c$.

nûn soi éxestin, $\hat{o}$ Xenophôn, andri

now you.2SG.DAT be.allowed.3SG.PRES oh! Xenophon man.DAT

genésthai

become.AOR.INF.MP

'Now you have the opportunity to prove yourself a man, o Xenophon!'

(Xen. Anab. 7.1.21) 
éxestin humin phílous genésthai

be.allowed.3SG.PRES you.2PL.DAT friends.ACC become.AOR.INF.MP

bebaíōs

firmly

'You can become firmly friends' (Thuc. 4.20)

\section{pareíkei}

See also exx. $42 a$ and $42 b$.

\section{dunatôs ékhei}

See ex. 43 .

\section{enkhōreî}

See also ex 45 .

enkhōrề autôi perì toútōn eidénai;

be.possible.3SG.IPFV self.DAT about this know.PFV.INF

'Can he know for certain?' (Antiph. 1 7)

ouk enkhōroie toîs pleonekteîn

not be.possible.3SG.PRES.OPT the have.advantage.INF

bouloménois mè ouk ekpodòn poieîsthai toùsikanōtátous

want.PRES.PART.MP.DAT PTC not away make.INF.MP themost.able.ACC diakōlúein

thwart.INF

'People who want to have advantage would not be able to put out of the way those most able to thwart them.' (Xen. Hell. 2.3.16)

hoîs t' enkhōrề tôn anthrópōn hubristaîs eînai kaì RP.DAT PTC be.possible.3SG.PRES the men.GEN insolent.DAT be.INF and ồ ou prosékei

RP.DAT not beseem.3SG.PRES

'[I expect you to need to distinguish] those who are able to insolent and those who it does not beseem.' (Lys. 24 15) 


\section{ekgígnetai}

See also ex. 47.

oud' ànapologésasthaí moi exegéneto

not defend.self.AOR.INF.MP I.1SG.DAT be.allowed.3SG.AOR.MP

'I was not allowed to defend myself' (Lys. 7 37)

humîn gàr exegénet' án, ... tèn protéran ekeínēn

you.2PL.DAT for be.allowed.3SG.AOR.MID PTC the former that.ACC

eirếnēn poiêsasthai

peace.ACC make.AOR.INF.MP

'for you could have made that former peace' (Aeschin. 358)

all' oud' apologếsasthai moi exegéneto

but not defend.self.AOR.INF.MP 1.1SG.DAT be.allowed.3SG.AOR.MID

'But I could not defend myself' (Dem. 43 9; see also Dem. 57 12)

oud' ideîn autoîs exegéneto tèn autôn

not see.INF self.DAT be.allowed.3SG.AOR.MID the very.ACC

'They were not allowed to see their very own [field]' (Isoc. 8 92)

\section{hupárkhei}

See also exx. $48 a(=52 b)$ and $48 b$.

hupárkhei te autoîs, ... aitían éxein

be.possible.3SG.PRES PTC self.DAT responsibility.ACC have.INF 'They could ... be responsible' (Andoc. 2 19)

all' omoíōs hupárkhei tèn autè̀n eînai mētéra but similarly be.possible.3SG.PRES the self.ACC be.INF mother.ACC 'But in a similar manner the very same woman can be the mother' (Isaeus 725 )

toîs dè turánnois oudèn hupárkhei toioûton the.DAT PTC ruler.DAT not.at.all be.possible.3SG.PRES such.as.this.ACC 'The rules could not at all (be) such as this' (Isoc. 24 )

aphikoménei hupárkhei autêi eudaímoni eînai arriving.AOR.PART.DAT be.possible.3SG.PRES self.DAT happy.DAT be.INF 'For that arriving it is possible to be happy' (Plat. Phaedo 81a) 
dêlon hóti hôi prôton mèn hupárkhei iatrôi

clearly that he.3SG.DAT first PTC be.possible.3SG.PRES doctor.DAT

eínai

be.INF

'It is clear that first he who could become a doctor' (Plat. Prot. 345a)

hoîón (estí)

See ex. 5 .

\section{References}

Allan, Rutger J. 2013. Exploring Modality's Semantic Space: Grammaticalization, Subjectification and the Case of ó $\varphi \varepsilon i \lambda \omega$. Glotta 89(1).1-46.

Allen, Cynthia L. 1995. Case Marking and Reanalysis: Grammatical Relations from Old to Modern English. Oxford: Oxford University Press.

Andrews, Avery. 1976. The vp Complement Analysis in Modern Icelandic. North Eastern Linguistic Society 6.1-21.

Barðdal, Jóhanna. 20ooa. The Subject is Nominative! On Obsolete Axioms and Their Deep-Rootedness. 17th Scandinavian Conference of Linguistics, ed. by Carl-Erik Lindberg \& Steffen Nordahl Lund, 93-117. Odense: Institute of Language and Communication.

Barðdal, Jóhanna. 2ooob. Oblique Subjects in Old Scandinavian. NOWELE: North-Western European Language Evolution 37.25-51.

Barðdal, Jóhanna. 20o1a. The Perplexity of Dat-Nom Verbs in Icelandic. Nordic Journal of Linguistics $24 \cdot 47-70$.

Barðdal, Jóhanna. 20o1b. Case in Icelandic-A Synchronic, Diachronic and Comparative Approach. Lundastudier i Nordisk språkvetenskap A 57. Lund: Department of Scandinavian Languages.

Barðdal, Jóhanna. 2004. The Semantics of the Impersonal Construction in Icelandic, German and Faroese: Beyond Thematic Roles. Focus on Germanic Typology [Studia Typologica 6], ed. by Werner Abraham, 105-137. Berlin: Akademie Verlag.

Barðdal, Jóhanna. 20o6. Construction-Specific Properties of Syntactic Subjects in Icelandic and German. Cognitive Linguistics 17(1).39-106.

Barðdal, Jóhanna. 2008. Productivity: Evidence from Case and Argument Structure in Icelandic. Amsterdam: John Benjamins.

Barðdal, Jóhanna. 20o9. The Development of Case in Germanic. The Role of Semantic, Pragmatic and Discourse Factors in the Development of Case, ed. by Jóhanna Barðdal \& Shobhana Chelliah, 123-159. Amsterdam: John Benjamins.

Barðdal, Jóhanna, Carlee Arnett, Stephen Mark Carey, Thórhallur Eythórsson, Gard 
B. Jenset, Guus Kroonen \& Adam Oberlin. 2016. Dative Subjects in Germanic: A Computational Analysis of Lexical Semantic Verb Classes Across Time and Space. STUF: Language Typology and Universals 69(1).49-84.

Barðdal, Jóhanna, Serena Danesi, Laura Bruno \& Roland Pooth. 2017. Oblique Subjects in Latin and Ancient Greek. Presented at the IG-2017 Arbeitstagung in Verona, 1114 October.

Barðdal, Jóhanna \& Thórhallur Eythórsson. 2003. The Change that Never Happened: The Story of Oblique Subjects. Journal of Linguistics 39(3).439-472.

Barðdal, Jóhanna \& Thórhallur Eythórsson. 20og. The Origin of the Oblique Subject Construction: An Indo-European Comparison. Grammatical Change in IndoEuropean Languages, ed. by Vit Bubenik, John Hewson \& Sarah Rose, 179-193. Amsterdam: John Benjamins.

Barðdal, Jóhanna \& Thórhallur Eythórsson. 2012. Reconstructing Syntax: Construction Grammar and the Comparative Method. Sign-Based Construction Grammar, ed. by Hans C. Boas \& Ivan A. Sag, 257-308. Stanford: CS Li Publications.

Barðdal, Jóhanna, Thórhallur Eythórsson \& Tonya Kim Dewey. 2014. Alternating Predicates in Icelandic and German: A Sign-Based Construction Grammar Account. Working Papers in Scandinavian Syntax 93.50-101.

Barðdal, Jóhanna \& Spike Gildea. 2015. Diachronic Construction Grammar: Epistemological Context, Basic Assumptions and Historical Implications. Diachronic Construction Grammar, ed. by Jóhanna Barðdal, Elena Smirnova, Lotte Sommerer \& Spike Gildea, 1-5o. Amsterdam: John Benjamins.

Barðdal, Jóhanna, Kristian E. Kristoffersen \& Andreas Sveen 2011. West Scandinavian Ditransitives as a Family of Constructions: With a Special Attention to the Norwegian V-RE FL-NP Construction. Linguistics 49(1).53-104.

Barðdal, Jóhanna, Thomas Smitherman, Valgerður Bjarnadóttir, Serena Danesi, Gard B. Jenset \& Barbara McGillivray. 2012. Reconstructing Constructional Semantics: The Dative Subject Construction in Old Norse-Icelandic, Latin, Ancient Greek, Old Russian and Old Lithuanian. Studies in Language 36(3).511-547.

Barnes, Michael. 1986. Subject, Nominative and Oblique Case in Faroese. Scripta Islandica $38.3-35$.

Benardete, S. 1965. XPH and $\Delta \mathrm{EI}$ in Plato and others. Glotta 43.285-298.

Benedetti, Marina \& Chiara Gianollo. 2017. Criteria for Subjecthood and Non-Canonical Subjects in Ancient Greek. Presented at ICHL 23, San Antonio, TX.

Bybee, Joan, Revere Perkins, \& William Pagliuca. 1994. The Evolution of Grammar: Tense, Aspect and Modality in the Languages of the World. Chicago: University of Chicago Press.

Cennamo, Michela. 2011. Impersonal Constructions and Accusative Subjects in Late Latin. Impersonal Constructions: A Cross-Linguistic Perspective, ed. by A. Malchukov \& A. Siewierska, 167-188. Amsterdam: John Benjamins. 
Chelliah, Shobhana L. 20o9. Semantic Role to New Information in Meithei. The Role of Semantic, Pragmatic, and Discourse Factors in the Development of Case, ed. by Jóhanna Barðdal \& Shobhana L. Chelliah, 337-40o. Amsterdam: John Benjamins.

Corbett, Greville G. 1991. Gender. Cambridge: Cambridge University Press.

Croft, William 1998. Event Structure in Argument Linking. The Projection of Arguments: Lexical and Compositional factors, ed. by Miriam Butt \& Wilhelm Geuder, 1-43. Stanford CA: CSLI Publications.

Croft, William. 2001. Radical Construction Grammar: Syntactic Theory in Typological Perspective. Oxford: Oxford University Press.

Croft, William. 2003. Lexical Rules vs. Constructions: A False Dichotomy. Motivation in Language: Studies in Honour of Günter Radden, ed. by Hubert Cuyckens, Thomas Berg, René Dirven \& Klaus-Uwe Panther, 49-68. Amsterdam: John Benjamins.

Croft, William \& D. Alan Cruse. 2004. Cognitive Linguistics. Cambridge: Cambridge University Press.

Dąbrowska, Ewa. 1997. Cognitive Semantics and the Polish Dative. Berlin: Mouton de Gruyter.

Danesi, Serena, Cynthia A. Johnson \& Jóhanna Barðdal. 2017. Between the Historical Languages and the Reconstructed Language: An Alternative Approach to the Gerundive + "Dative of Agent" Construction in Indo-European. Indogermanische Forschungen 122.143-188.

Eythórsson, Thórhallur \& Jóhanna Barðdal. 2005. Oblique Subjects: A Common Germanic Inheritance. Language 81.824-881.

Fabrizio, Claudia. In press. Non-nominative subjects in Latin. *Rotamanas-, Rotavacas-, Rtadipi- *-'OfRight Thoughts, Right Speech, Right Writings': Studies in Honor of Rüdiger Schmitt, ed. by K. Stüber \& V. Sadovski. Vienna: Austrian Academy of Sciences Press.

Fedriani, Chiara. 2009. The "Behaviour-Before-Coding" Principle: Further Evidence from Latin. Archivio Glottologico Italiano XCIV(II).156-184.

Fedriani, Chiara. 2014. Experiential Constructions in Latin. Leiden: Brill.

Fillmore, Charles J., Paul Kay \& Mary Catherine O'Connor. 1988. Regularity and Idiomaticity in Grammatical Constructions: The Case of Let Alone. Language 64.501-538.

Fischer, Kerstin \& Maria Alm. 2013. A Radical Construction Grammar Perspective on the Modal Particle-Discourse Particle Distinction. Discourse Markers and Modal Particles: Categorization and Description, ed. by Liesbeth Degand, Bert Cornillie \& Paola Pietrandrea, 47-87. Amsterdam:John Benjamins.

Fried, Mirjam. 2005. A Frame-Based Approach to Case Alternations: The Swarm-Class Verbs in Czech. Cognitive Linguistics 16.475-512.

Gianollo, Chiara \& Nikolaos Lavidas. 2013. Cognate Adverbials and Case in the History of Greek. Studies in Greek Linguistics 33.61-75.

Gianollo, Chiara \& Nikolaos Lavidas. 2014. Greek Cognate Datives: From Modification 
to Focus. Selected Papers from the nth International Conference on Greek Linguistics, ed. by G. Kotzoglou, K. Nikolou, E. Karantzola, K. Frantzi, I. Galantomos, M. Georgalidou, V. Kourti-Kazoullis, Ch. Papadopoulou \& E. Vlachou, 488-50o. Rhodes: University of the Aegean.

Goldberg, Adele E. 1995. Constructions: A Construction Grammar Approach to Argument Structure. Chicago: University of Chicago Press.

Goldberg, Adele E. 20o6. Constructions at Work: The Nature of Generalization in Language. Oxford: Oxford University Press.

Goodell, T.D. 1914. XPH and $\Delta$ EI. Classical Quarterly 8.91-102.

Goodwin, William Watson. 1966 [1875]. Syntax of the Moods and Tenses of the Greek Verb. New York, NY: St Martin's Press.

Grillborzer, Christine. 2014. Sintaksis konstrukcij s pervym datel'nym aktantom-Sinchronnyj i diachronnyj analiz. Regensburg University PhD Thesis.

Hanson, Kristin. 1987. On Subjectivity and the History of Epistemic Expressions in English. Chicago Linguistic Society 23.133-147.

Hilpert, Martin. 2014. Construction Grammar and its Application to English. Edinburgh: Edinburgh University Press.

Hock, Hans H. 1990. Oblique subjects in Sanskrit? Experiencer Subjects in South Asian Languages ed. by M.K. Verma \& K.P. Mohanan, 119-139. Stanford: CSLI Publication.

Hopper, Paul \& Elizabeth Closs Traugott. 1993. Grammaticalization. Cambridge: Cambridge University Press.

Horrocks, Geoffrey. 1995. On Condition, Aspect and Modality in the History of Greek. Proceedings of the Cambridge Philological Society 41.153-173.

Johnson, Cynthia A., Michael Frotscher, Esther Le Mair \& Jóhanna Barðdal. In prep. What is "Freedom" of Word Order? Position as a Subject Behavior in Hittite. Ms. Ghent University.

Jónsson, Jóhannes Gísli. 2018. Word Order as a Subject Test in Old Icelandic. NonCanonically Case-Marked Subjects within and across Language Families: The Reykjavík-Eyjafjallajökull Papers, ed. by Jóhanna Barðdal, Na’ama Pat-El, \& Stephen Mark Carey. Amsterdam: John Benjamins. In press.

Klaiman, Miriam H. 1980. Bengali Dative Subjects. Lingua 51(4).275-295.

Kulikov, Leonid. 2011. Passive to Anticausative through Impersonalization: The Case of Vedic and Indo-European. Impersonal Constructions: A Cross-Linguistic Perspective, ed. by A. Malchukov \& A. Siewierska, 229-254. Amsterdam: John Benjamins.

Lakoff, George. 1987. Women, Fire, and Dangerous Things: What Categories Reveal About the Mind. Chicago: University of Chicago Press.

Langacker, Ronald W. 1987. Foundations of Cognitive Grammar, Volume 1:Theoretical Prerequisites. Stanford, CA: Stanford University Press.

La Fauci, Nunzio \& Liana Tronci. 2013. Categorie e relazioni: morfosintassi di aggettivi 
verbali in greco antico. Le lingue del Mediterraneo antico: Culture, mutamenti, contatti, ed. by Marco Mancini \& Luca Lorenzetti, 193-212. Roma: Carocci.

Le Mair, Esther, Cynthia A. Johnson, Michael Frotscher, Thórhallur Eythórsson \& Jóhanna Barðdal. 2017. Position as a Behavioral Property of Subjects: The Case of Old Irish. Indogermanische Forschungen 122: 111-142.

Levshina, Natalia. 2012. Comparing Constructicons: A Usage-Based Analysis of the Causative Construction with Doen in Netherlandic and Belgian Dutch. Constructions and Frames $4(1) \cdot 76-101$.

Luraghi, Silvia. 2016. The Dative of Agent in Indo-European Languages. STUF: Language Typology and Universals 69(1).15-47.

Masica, Colin P. 1976. Defining a Linguistic Area: South Asia. Chicago: University of Chicago Press.

Michaelis, Laura A. \& Josef Ruppenhofer. 2001. Beyond Alternations: A Constructional Model of the German Applicative Pattern. Stanford: CSLI Publications.

Narrog, Heiko. 2005. Modality, Mood and Change of Modal Meanings: A New Perspective. Cognitive Linguistics 16.677-731.

Narrog, Heiko. 2012. Modality, Subjectivity, and Semantic Change: A Cross-Linguistic Perspective. Oxford: Oxford University Press.

Nunberg, Geoffrey, Ivan A. Sag \& Thomas Wasow. 1994. Idioms. Language 70.491538.

Onishi, Masayuki. 2001. Introduction: Non-Canonically Marked Subjects and Objects: Parameters and Properties. Non-Canonical Marking of Subjects and Objects, ed. by Alexandra Y. Aikhenvald, R.M.W. Dixon \& Masayuki Onishi, 1-51. Amsterdam: John Benjamins.

Papangeli, Dimitra. 2004. The Morphosyntax of Argument Realization: Greek Argument Structure and the Lexicon-Syntax Interface. Utrecht University PhD Thesis.

Paradis, Carita. 2001. Adjectives and Boundedness. Cognitive Linguistics 12.47-64.

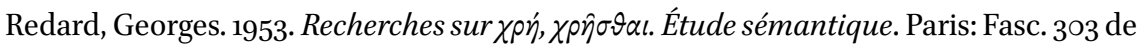
la Bibliothèque de l'École des Hautes Études.

Rögnvaldsson, Eiríkur. 1991. Quirky Subjects in Old Icelandic. Papers from the Twelfth Scandinavian Conference of Linguistics, ed. by Halldór Ármann Sigurðsson, 369-387. Reykjavík: Institute of Linguistics, University of Iceland.

Rögnvaldsson, Eiríkur. 1995. Old Icelandic: A Non-Configurational Language? NOWELE: North-Western European Language Evolution 26.3-29.

Rögnvaldsson, Eiríkur. 1996. Frumlag og fall að fornu [Subject and Case in Old Icelandic]. Íslenskt mál og almenn málfrceði 18.7-69.

Ruiz Yamuza, Emilia. 2008. Tresverbos que significan 'deber'en griego antiguo. Zaragoza: Libros Pórtico.

Sadler, Misumi. 2009. From Less Personal to More Personal: Subjectification of $N i$ Marked NPs in Japanese Discourse. The Role of Semantic, Pragmatic, and Discourse 
Factors in the Development of Case, ed. by Jóhanna Barðdal \& Shobhana L. Chelliah, 401-422. Amsterdam: John Benjamins.

Seiler, Hansjakob. 1971. Abstract Structures for Moods in Greek. Language 47(1).79-89. Sigurðsson, Halldór Ármann. 1990-1991. Beygingarsamræmi [Agreement]. Íslenskt mál og almenn málfrceði 12-13·31-77.

Sigurðsson, Halldór Ármann. 2006. Agree in Syntax, Agreement in Signs. Agreement Systems, ed. by C. Boeckx, 201-237. Amsterdam: John Benjamins.

Smyth, Herbert Weir. 1963. [1920] Greek Grammar. Harvard: Harvard University Press. Smyth, Herbert Weir \& Gordon M. Messing. 1956. Greek Grammar. Cambridge, MA: Harvard University Press.

Sweetser, Eve E. 199o. From Etymology to Pragmatics: Metaphorical and Cultural Aspects of Semantic Structure. Cambridge: Cambridge University Press.

Talmy, Leonard. 1988. Force Dynamics in Language and Cognition. Cognitive Science 12(1).49-100.

Thráinsson, Höskuldur, Hjalmar P. Petersen, Jógvan í Lon Jacobsen \& Zakaris S. Hansen. 2012. Faroese: An Overview and Reference Grammar. Second edition. Tórshavn: Føroya Fróðskaparfelag.

Tomasello, Michael. 1998. Cognitive Linguistics. A Companion to Cognitive Science, ed. by William Bechtel \& George Graham, 477-487. Oxford: Blackwell.

Torrent, Tiago Timponi. 2015. On the Relation Between Inheritance and Change: The Constructional Convergence and the Construction Network Reconfiguration Hypotheses. Diachronic Construction Grammar, ed. by Jóhanna Barðdal, Elena Smirnova, Lotte Sommerer \& Spike Gildea, 173-212. Amsterdam: John Benjamins.

Traugott, Elizabeth Closs. 1989. On the Rise of Epistemic Meanings in English: An Example of Subjectification in Semantic Change. Language 65.31-55.

Traugott, Elizabeth Closs. 1995. Subjectification in Grammaticalization. Subjectivity and Subjectivisation, ed. by Dieter Stein \& Susan Wright, 37-54. Cambridge: Cambridge University Press.

Traugott, Elizabeth Closs. 2003. From Subjectification to Intersubjectification. Motives for Language Change, ed. by Raymond Hickey, 124-139. Cambridge: Cambridge University Press.

Traugott, Elizabeth Closs \& Richard B. Dasher. 2002. Regularity in Semantic Change. Cambridge: Cambridge University Press.

Traugott, Elizabeth Closs \& Graeme Trousdale. 2013. Constructionalization and Constructional Change. Oxford: Oxford University Press.

Trousdale, Graeme. 2013. Multiple Inheritance and Constructional Change. Studies in Language 37(3).491-514.

van der Auwera, Johan \& Vladimir Plungian. 1998. Modality's Semantic Map. Linguistic Typology 2(1).79-124.

Willmott, Jo. 2007. The Moods of Homeric Greek. Cambridge: Cambridge University Press. 